observed percent ${ }^{18} \mathrm{O}$ incorporation the scrambling rates were calculated by standard methods ${ }^{16}$.

Two control experiments in each solvent were performed in order to show that the observed ${ }^{18} \mathrm{O}$ scrambling is not the result of (1) chemical workup or (2) external ion return. In the first experiment $25 \mathrm{mg}$ of the labeled ester was dissolved in the buffered solvent $(25 \mathrm{~mL})$ containing 1 equiv of 2,6-lutidinium brosylate, and the reaction mixture was worked up immediately in the same manner. In the second experiment $50 \mathrm{mg}$ of the unlabeled sulfonate ester was dissolved in the buffered solvent ( 25 $\mathrm{mL}$ ) containing I equiv of ${ }^{18} \mathrm{O}$ enriched $(60.7 \%) 2$,6-lutidinium brosylate and after solvolysis for 1 half-life the solution was worked up in the same manner. In the ${ }^{13} \mathrm{C}$ NMR spectrum of the isolated ester from both experiments, no ${ }^{18} \mathrm{O}$ was observed to be present at the $\alpha$-carbon.

Oxygen Scrambling Studies. 2. 4-Methyl-3-homoadamantyl Heptafluorobutyrate. A $5.3 \mathrm{mM}$ solution of the ether ${ }^{18} \mathrm{O}$ enriched $(50.70 \%)$ 4-methyl-3-homoadamantyl heptafluorobutyrate in $80 \mathrm{E}(100 \mathrm{mg} / 50 \mathrm{~mL})$ containing a 1.1 equiv of 2,6 -lutidine was reacted at $25^{\circ} \mathrm{C}$ for $9.51 \mathrm{~h}$. The reaction flask was then placed in a $0^{\circ} \mathrm{C}$ bath, and the workup was the same as that used in the ${ }^{18} \mathrm{O}$ studies of $2 \mathrm{a}$. The composition of the product mixture was analyzed by ${ }^{1} \mathrm{H}$ NMR $(300 \mathrm{MHz})$ in an analogous fashion to that performed in the product studies of the tertiary ester above. In the spectrum the additional methyl doublet of the unreacted tertiary ester occurs at $0.93 \mathrm{ppm}$. The percentage ${ }^{18} \mathrm{O}$ incorporation at the $\alpha$-carbon of the two esters and of the solvolysis products was determined from the natural abundance $125-\mathrm{MHz}{ }^{13} \mathrm{C}$ spectrum recorded on a Bruker $500-\mathrm{MHz}$ Fourier transform spectrometer with the conditions for data acquisition being similar to those in the ${ }^{18} \mathrm{O}$ studies of $2 \mathrm{a}$. No ${ }^{18} \mathrm{O}$ incorporation was observed at the $\alpha$-carbon of the alcohol and ether solvolysis products. In the unreacted tertiary ester and the rearranged secondary ester the percent ${ }^{18} \mathrm{O}$ present was $43.68 \%$ and $41.56 \%$, respectively, and their recorded spectra are shown in Figure 3. The proportion of unreacted tertiary ester that was equilibrated is $27.7 \%$ [ $(50.7$ $-43.68) / 23.35 \times 100]$ while that for the secondary ester was $36.0 \%$. The calculation of the rate of ${ }^{18} \mathrm{O}$ equilibration $\left(9.47 \times 10^{-6} \mathrm{~s}^{-1}\right)$ for the tertiary ester as well as the ratio of return of the originally bonded oxygen relative to the carbonyl oxygen (6.6:1) which occurs in the formation of the secondary ester from unscrambled tertiary ester is given in detail in the Supplementary Material. ${ }^{36}$
Solvent Preparation. UV and Conductance Kinetic Procedures. The procedures were the same as those which have been previously reported . $^{5}-\mathrm{f}, 37,38$

Acknowledgment. This material is based upon work supported by the National Science Foundation under grants CHE 85-06682 (project support), CHE 81-05004 (Nicolet 360 NMR), CHE85-13707 (Bruker 500 NMR) and CHE-81-11957 (Kratos GC/MS 80). Additional support was supplied by the National Institutes of Health under grants PHS-S10-RR-1882-01 (Varian 300 NMR) and PHS-S10-RR-3956-01 (Bruker 500 NMR). The authors gratefully acknowledge the assistance of Janet Coope in acquiring the $55-\mathrm{MHz}{ }^{2} \mathrm{H}$ NMR spectra.

Supplementary Material Available: The details of and the equations used in the Simplex calculation of Scheme I (12 pages). Ordering information is given on any current masthead page.

(36) These calculations were determined from the equations derived by the integration factor method for the following scheme:

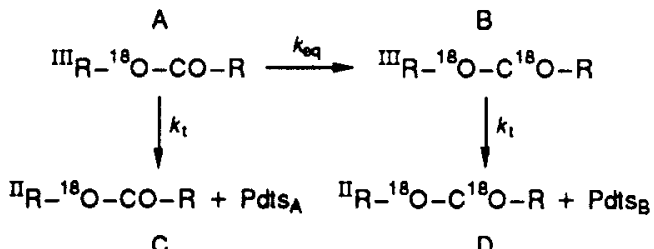

which takes into account that the secondary ester ( $C$ and $D)$ is formed both from unscrambled starting ester $(A)$ and from ester that has been scrambled (B) durining the course of reaction.

(37) Seib, R. C.: Shiner, V. J., Jr.; Sendijarevic, V.: Humski, K. J. Am. Chem. Soc. 1978, 100, 8133-8137.

(38) Ensinger, M. W. Ph.D. Thesis, Indiana University, Bloomington, 1987

(39) Wilgis, F. P., Ph.D. Thesis, Indiana University, Bloomington, 1989.

\title{
Addition Reactions of Diarylcarbenium Ions to 2-Methyl-1-pentene: Kinetic Method and Reaction Mechanism ${ }^{\ddagger}$
}

\author{
Herbert Mayr,* Reinhard Schneider, Christian Schade, Jörg Bartl, and Rainer Bederke ( $^{\S}$ \\ Contribution from the Institut für Chemie, Medizinische Universität zu Lübeck, Ratzeburger \\ Allee 160, D-2400 Lübeck, Federal Republic of Germany. Received October 25, 1989
}

\begin{abstract}
A kinetic method that allows the determination of reactivities of carbenium ions toward alkenes is described: Diarylmethyl chlorides (1) are completely ionized by $\mathrm{BCl}_{3}$ in $\mathrm{CH}_{2} \mathrm{Cl}_{2}$ to give colored solutions of diarylcarbenium (2) tetrachloroborates, which show conductivity. Upon addition of the model alkene 3 (2-methyl-1-pentene) conductance and absorbance disappear due to the formation of the covalent and colorless adducts $5\left(\mathrm{Ar}_{2} \mathrm{CH}^{+} \cdot \mathrm{BCl}_{4}^{-}+\mathrm{H}_{2} \mathrm{C}=\mathrm{C}\left(\mathrm{CH}_{3}\right) \mathrm{C}_{3} \mathrm{H}_{7} \rightarrow\right.$ $\left.\mathrm{Ar}_{2} \mathrm{CHCH}_{2} \mathrm{C}\left(\mathrm{CH}_{3}\right)\left(\mathrm{C}_{3} \mathrm{H}_{7}\right) \mathrm{Cl}+\mathrm{BCl}_{3}\right)$. The second-order reactions are linear with respect to the concentration of carbenium ions and of the alkene. Free and paired ions exhibit identical reactivity. The attack of the carbenium ions 2 on the alkene

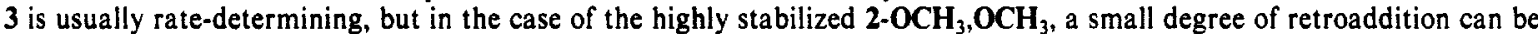
detected. Variation of the para substituents, $\mathrm{X}$ and $\mathrm{Y}$, in the carbenium ions 2 alters $\Delta H^{*}$ while $\Delta S^{*}$ remains unaffected Variation of solvent polarity has a very small effect on the addition rates $\left(k_{\mathrm{CH}_{3} \mathrm{NO}_{2}} / k_{\mathrm{CHCl}_{3}}=5\right)$. Kinetic isotope effects $\left(k_{\mathrm{H}} / k_{\mathrm{D}}\right.$ $\approx 0.8$ ) and rate equilibrium relationships indicate a late transition state for the reaction of 2 with 3 . In some cases, the rates of ionization of the diarylmethyl chlorides 1 can be measured. Solvolytic studies on the adducts 5 allow the derivation of the energy of the intermediates 4 . Complete energy profiles for the multistep reaction sequence (1) are elaborated.
\end{abstract}

\section{Introduction}

The formation of $\mathrm{CC}$ bonds via attack of carbon electrophiles at $\mathrm{CC}$ double bonds is an important method in synthetic organic ${ }^{1}$ and macromolecular chemistry. ${ }^{2}$ While extensive mechanistic investigations have been carried out on various electrophilic re-

\footnotetext{
tThis and the following two articles are dedicated to our teacher P. v. R. Schleyer on the occasion of his 60th birthday.
}

Fachhochschule Lübeck. actions on alkenes, ${ }^{3}$ including halogenations, hydroborations, sulfenylations, oxymercurations, and proton additions, relatively

(1) Reviews: (a) Olah, G. A. Friedel-Crafts and Related Reactions Interscience: New York, 1963-1965; Vol. I-IV. (b) Olah, G. A. Friedel Crafts Chemistry; Wiley Interscience: New York, 1973. (c) Roberts, R. M.; Khalaf, A. A. Friedel-Crafts Alkylation Chemistry; Marcel Dekker: New York, 1984. (d) Mathieu, J.; Weill-Raynal, J. Formation of C-C Bonds Georg Thieme: Stuttgart, 1973-1979; Vols. I-III. 
Scheme I<smiles>[Y]c1ccc([CH][CH]c2ccc([Y])cc2)cc1</smiles>

$X \quad \mathrm{CH}_{3} \quad \mathrm{OPh} \quad \mathrm{OCH}_{3} \quad \mathrm{OCH}_{3} \quad \mathrm{OPh} \quad \mathrm{OCH}_{3}$

$\begin{array}{llllllll}\mathrm{Y} & \mathrm{CH}_{3} & \mathrm{CH}_{3} & \mathrm{H} & \mathrm{CH}_{3} & \mathrm{OCH}_{3} & \mathrm{OCH}_{3}\end{array}$

little is known about the reactions of carbenium ions with alkenes. Stereochemical investigations led to the conclusion that the transition state of diarylcarbenium ion additions toward alkenes is weakly bridged. ${ }^{4}$ The same conclusion was drawn from relative reactivities of alkenes toward diarylcarbenium ions, which were determined by competition experiments. ${ }^{5}$ Dorfman's kinetic study on the reactions of radiolytically generated benzyl and benzhydryl cations with some alkenes and dienes has been the only source for absolute rate constants of such reactions. ${ }^{6}$ The determination of such rate constants under "normal chemical conditions" is problematic because of complications caused by competing polymerizations and by the reversibility of the addition step. Since such data are needed for the design of synthetic methods in organic ${ }^{7}$ and macromolecular chemistry, ${ }^{2 b}$ we are presently performing a systematic investigation of the reactions of carbon electrophiles with $\pi$-nucleophiles. In this article, we describe a kinetic method, which has been developed for determining carbenium ion reactivities toward alkenes, employing the additions of diarylmethyl chlorides toward 2-methyl-1-pentene as model reactions (eq 1$)^{8}$
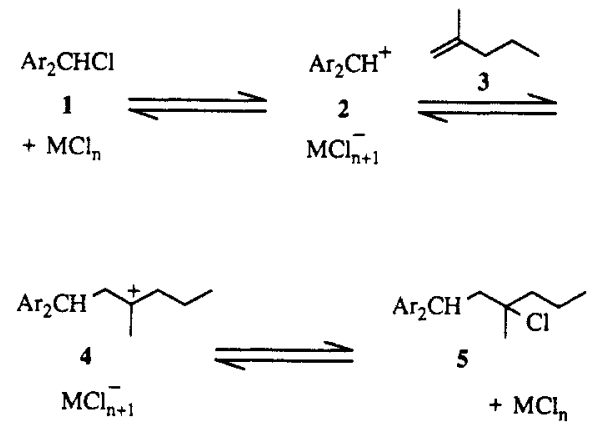

\section{Reaction Products}

In previous work we have shown that diarylmethyl chlorides and 1,1-dialkylethylenes give high yields of $1: 1$ addition products in presence of weak Lewis acids, e.g. $\mathrm{ZnCl}_{2} /$ Ether, ${ }^{5 \mathrm{a}, \mathrm{b}}$ Analogously, the diarylcarbenium tetrachloroborates $\left(2 \cdot \mathrm{BCl}_{4}^{-}\right)$, which are obtained from 1 and $\mathrm{BCl}_{3}$ in $\mathrm{CH}_{2} \mathrm{Cl}_{2}$, react with 2-methyl-

(2) Reviews: (a) Plesch, P. H., Ed. The Chemistry of Cationic Polymerization; Pergamon Press: New York, 1963. (b) Kennedy, J. P.; Maréchal, E. Carbocationic Polymerization; Wiley-Interscience: New York, 1982. (c) Gandini, A.; Cheradame, H. Advances in Polymer Science; Springer: Berlin, 1980; Vol. 34/35.

(3) Reviews: (a) Fahey, R. C. In Topics in Sterochemistry; Eliel, E. L., Allinger, N. L., Eds.; Interscience: New York, 1968; Vol. 3, p 237. (b) Schmid, G. H.; Garrat. D. G. In The Chemistry of Double-Bonded Functional Groups; Patai, S., Ed.; Wiley: New York, 1977; Supplement A, Part 2, p 725. (c) De la Mare, P. B. D.; Bolton, R. Electrophilic Additions to Unsaturated Systems; Elsevier: Amsterdam, 1982. (d) Freeman, F. Chem. Rev. 1975, 75, 439 .

(4) Pock, R.; Mayr, H.; Rubow, M.; Wilhelm, E. J. Am. Chem. Soc. 1986, 108,7767 .

(5) (a) Mayr, H.; Pock, R. Chem. Ber. 1986, 119, 2473. (b) Pock, R.; Mayr, H. Chem. Ber. 1986, 119, 2497. (c) See also: Melloni, G.; Modena, G.; Tonellato, U. Acc. Chem. Res. 1981, 14, 227.

(6) Wang, Y.; Dorfman, L. M. Macromolecules 1980, 13, 63.

(7) Mayr, H. In Selectivities in Lewis Acid-Promoted Reactions; Schinzer, D., Ed.; Reidel Publishing Company, in press.

(8) Preliminary communication: Schneider, R.; Grabis, U.: Mayr, H Angew. Chem. 1986, 98, 94; Angew. Chem., Int. Ed. Engl. 1986, 25, 89.

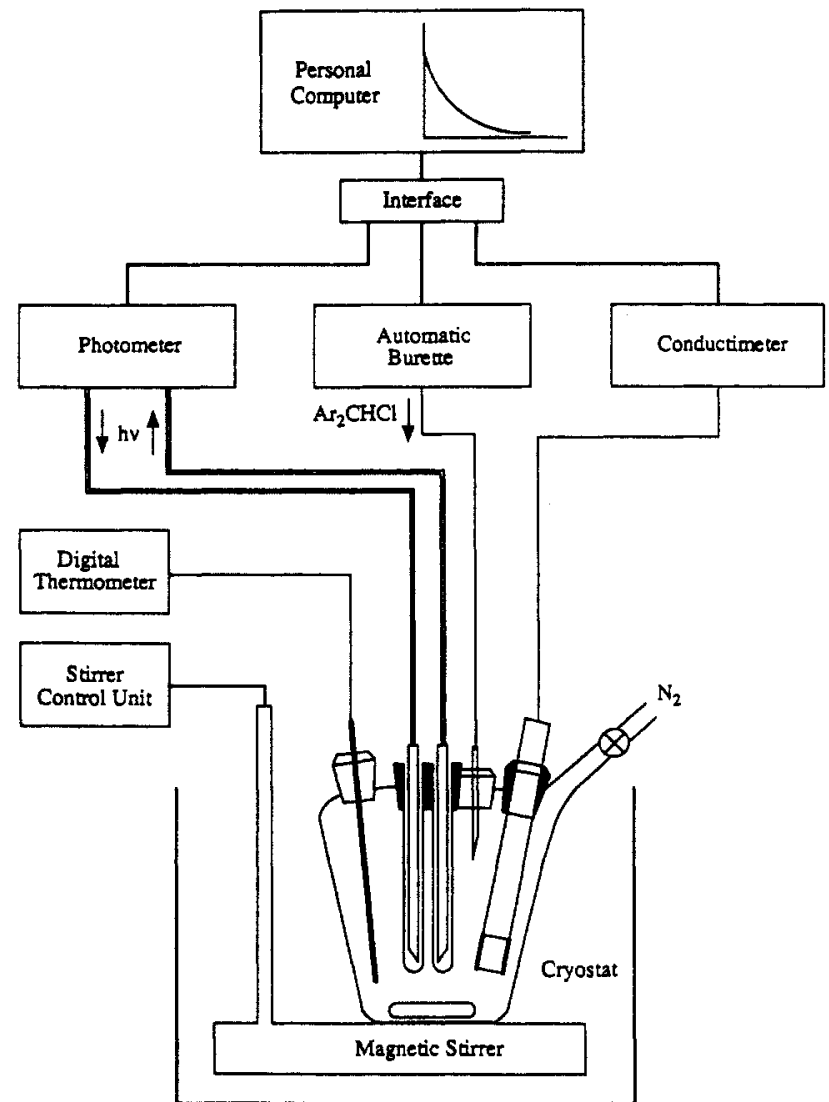

Figure 1. Work station for determining reactivities of diarylcarbenium ions.

1-pentene (3) at $-78^{\circ} \mathrm{C}$ to give the $1: 1$ adducts 5 in quantitative yield. ${ }^{9 a, 12}$ For $\mathrm{X} \neq \mathrm{Y}$, mixtures of diastereoisomers $(\sim 1: 1)$ were obtained, which were recognized by the twinning of several resonances in the NMR spectra. ${ }^{10}$ Lewis acid promoted cyclization of 5-X,Y with formation of indans, which takes place in presence of stronger Lewis acids or at elevated temperatures, was not observed under these conditions (Scheme I).

\section{Kinetic Method}

The yellow or red solutions of $2-\mathrm{X}, \mathrm{Y} \cdot \mathrm{BCl}_{4}^{-}$are electric conductors. ${ }^{11}$ When alkenes, like 3 , are added, color and conductance disappear due to the formation of covalent, colorless 5-X,Y and of $\mathrm{BCl}_{3}$. The course of the reactions can be monitored by determining absorbance and/or conductance. Though the ionization of diarylmethyl chlorides 1 to give diarylcarbenium ions $\mathbf{2}$ can be achieved with a variety of Lewis acids, in most of our mechanistic investigations boron trichloride has been employed for several reasons: (a) Its chloride affinity is sufficient to fully ionize diarylmethyl chlorides substituted by two methyl groups or better donors ${ }^{11}$ and weak enough to allow a rapid transfer of a chloride ion from $\mathrm{BCl}_{4}^{-}$to the tertiary carbenium ion 4 , thus avoiding polymerization of $3 . .^{12}$ (b) Since boron does not adopt coordination numbers $>4$ and $\mathrm{BCl}_{4}{ }^{-}$does not aggregate with $\mathrm{BCl}_{3}$, simple $1: 1$ ionization equilibria result." (c) Halogen exchange, which can take place with Lewis acids $\mathrm{MX}_{n}(\mathrm{X} \neq \mathrm{Cl})$, is avoided. (d) Diarylcarbenium tetrachloroborates readily dissolve in $\mathrm{CH}_{2} \mathrm{Cl}_{2}$ at $-70^{\circ} \mathrm{C}\left(<5 \times 10^{-3} \mathrm{~mol} \mathrm{~L}^{-1}\right)$ while the salts obtained from 1

(9) (a) Schneider, R. Dissertation, Universität Erlangen-Nürnberg, 1987. (b) Schade, C. Dissertation, Medizinische Universität zu Lübeck, 1988.

(10) Characterization of $\mathbf{5}-\mathbf{C H}_{3}, \mathbf{C H}_{3}$ : Reference $5 \mathbf{a}$; for other adducts, see ref $9 \mathrm{a}$.

(11) Schneider, R.; Mayr, H.; Plesch, P. H. Ber. Bunsenges. Phys. Chem. $1987,91,1369$.

(12) The polymerization of isobutene takes place under closely similar conditions, if a high alkene concentration is employed. Reviews: (a) Reference 2b, pp 204, 449. (b) Nuyken, O.; Pask, S. D.; Vischer, A.; Walter, M. Makromol. Chem., Macromol. Symp. 1986, 3, 129 . (c) Freyer, C. V.; Mühlbauer, H.-P.; Nuyken, O. Angew. Makromol. Chem. 1986, 145/l 146, 69." 
with $\mathrm{SnCl}_{4}, \mathrm{TiCl}_{4}$, or $\mathrm{SbCl}_{5}$ usually precipitate for [2] > (1-5) $\times 10^{-5} \mathrm{~mol} \mathrm{~L}^{-1}$ at $-70^{\circ} \mathrm{C}$.

\section{Experimental Section}

Dichloromethane (Merck, puriss.) was vigorously stirred over concentrated $\mathrm{H}_{2} \mathrm{SO}_{4}$ to remove traces of olefins $(24 \mathrm{~h}$ ), washed with $5 \%$ aqueous $\mathrm{K}_{2} \mathrm{CO}_{3}$ solution and water, and dried over $\mathrm{CaCl}_{2}$. The solvent was then refluxed over $\mathrm{P}_{4} \mathrm{O}_{10}$ for $24 \mathrm{~h}$ and distilled. Dichloromethane purified in this way, was freshly distilled over $\mathrm{CaH}_{2}$ before the kinetic experiments.

Chloroform (Merck, p.A., stabilized with 0.6-1\% ethanol) was stirred twice with concentrated $\mathrm{H}_{2} \mathrm{SO}_{4}$ for $10 \mathrm{~h}$ and washed with water and $5 \%$ aqueous $\mathrm{K}_{2} \mathrm{CO}_{3}$ solution. The solvent was dried over $\mathrm{CaCl}_{2}$, then over $\mathrm{P}_{4} \mathrm{O}_{10}$, and stored over $\mathrm{K}_{2} \mathrm{CO}_{3}$. Prior to use, the solvent was filtered over basic alumina (Merck, activity grade 1 ).

1,2-Dichloroethane (Merck, puriss. 99\%) was purified as described for $\mathrm{CH}_{2} \mathrm{Cl}_{2}$, but treatment with $\mathrm{P}_{4} \mathrm{O}_{10}$ was carried out at room temperature. Distillation through a $40-\mathrm{cm}$ column gave a central fraction with bp 83.6 ${ }^{\circ} \mathrm{C}$ (1024 mbar).

Nitromethane and nitroethane (Merck, zur Synthese) were not obtained in sufficient quality when dried over $\mathrm{P}_{4} \mathrm{O}_{10}$. Column chromatography through neutral alumina (Merck, activity grade 1) without further distillation gave solvents of satisfactory purity.

Benzyltriethylammonium chloride (EGA, 97-99\%) was dried in small portions $(100-250 \mathrm{mg})$ at $100^{\circ} \mathrm{C}(0.2 \mathrm{mbar})$ for $30 \mathrm{~min}$ immediately before use.

All experiments were performed under strictly anhydrous conditions. Since the kinetic investigations were carried out in rather dilute solution, the purity of the solvents was critical. Impure solvents were easily recognized by inconstancy of the carbenium ion absorbance during the ionization procedure.

Kinetics of the Carbenium Ion Additions. The experiments are carried out in a $150-\mathrm{mL}$ four-necked flask placed over a magnetic stirrer ${ }^{13}$ in a cryostat $\left(-90\right.$ to $\left.-20^{\circ} \mathrm{C}\right)$, as depicted schematically in Figure 1 .

The photometric measurements are performed with a fiber optics system (Schölly KGS III) developed by Kunz and Hallensleben. ${ }^{14}$ The light of a 30-W halogen lamp is conducted in a liquid fiber, which splits the beam into a probe channel and a reference channel. As indicated in Figure 1, the probe consists of two parallel quartz rods, inserted into two quartz tubes, which are immersed into the solution to be analyzed. The light travels down one rod, is totally reflected at its lower end to pass through the solution $(\approx 5 \mathrm{~mm})$ and then returns by the second rod, where a liquid fiber conducts it through an interference filter (Bandpass-Filter Corion) to the signal monitor. Conductimetric measurements are carried out with a Tacussel CD 810 conductimeter and Pt plate electrodes. The cell constants, determined with $0.01 \mathrm{M}$ and $0.001 \mathrm{M} \mathrm{KCl}$ solutions, range from 53 to $85 \mathrm{~m}^{-1}$. Conductances below $10 \mu \mathrm{S}$ are determined with $62.5-\mathrm{Hz} \mathrm{AC}$, and for those between 10 and $50 \mu \mathrm{S}$, an $\mathrm{AC}$ of $250 \mathrm{~Hz}$ is used.

Typical Procedure. The reaction flask is heated, evacuated, and flushed with $\mathrm{N}_{2}$ (3-4 times) before it is filled with $100.0 \mathrm{~mL}$ of dry $\mathrm{CH}_{2} \mathrm{Cl}_{2}\left(V_{\mathrm{O}}\right)$ at $20^{\circ} \mathrm{C}$. After the flask was placed into the cooling bath of the thermostat, gaseous $\mathrm{BCl}_{3}$ is injected through a septum with a gas-tight syringe. After reaching the temperature for the kinetic experiment, a solution of the diarylmethyl chloride 1 in $\mathrm{CH}_{2} \mathrm{Cl}_{2}$ is added in $i$ portions via an automatic buret, which is controlled by a personal computer (IBM-XT). After the addition of each portion, conductance and absorbance are measured and their values stored ${ }^{152}$ together with the calculated carbenium ion concentration [2], where $i=$ number of portions

$$
[2]=i c_{\mathrm{T}} V_{\mathrm{Z}}(1+\Delta T f) /\left(V_{\mathrm{O}}+i V_{\mathrm{Z}}\right)
$$

of the solution of $1, c_{\mathrm{T}}=$ concentration of the solution of 1 (at ambient temperature), $V_{Z}=$ volume of one portion, $V_{0}=$ volume of $\mathrm{CH}_{2} \mathrm{Cl}_{2}$ at ambient temperature, $\Delta T=T$ (ambient) $-T$ (probe), $f=$ expansion coefficient of the solvent $\left(0.00139 \mathrm{~K}^{-1}\right.$ for $\left.\mathrm{CH}_{2} \mathrm{Cl}_{2}\right)$. ${ }^{16}$

In a typical experiment, $i=125$ portions of $V_{2}=0.040 \mathrm{~mL}$ with $c_{\mathrm{T}}$ $=0.00100 \mathrm{~mol} \mathrm{~L}^{-1}$ are added within $40 \mathrm{~min}$. Since the calibration curves

(13) The magnetic stirrer consists of 4 electromagnets, which are placed in an aluminum box (tightened with a Teflon ribbon). The connection between a stepper motor controller and the electromagnets is conducted through a brass tube which is welded with the top part of the aluminum box.

(14) (a) Kunz, D.; Hallensleben, M. Chem. Tech. 1983, 12, 67. (b) Dittmer, T.; Nuyken, O.: Pask. S. J. Chem. Soc., Perkin Trans. 2 1988, 151.

(15) (a) Conductance and absorbance values are stored as soon as ten consecutive measurements (usually carried out in $0.3 \mathrm{~s}$ intervals) fulfil a constancy criterion. (b) For $[2]_{0}=[3]_{0}$, the equation $k_{2} t=1 /[2]_{1}-1 /[2]_{0}$ was used

(16) Riddick, J. A.; Bunger, W. B.; Sakano, T. K. In Techniques of Chemistry, 4th ed.; Wiley: New York, 1986; Vol. II, p 490

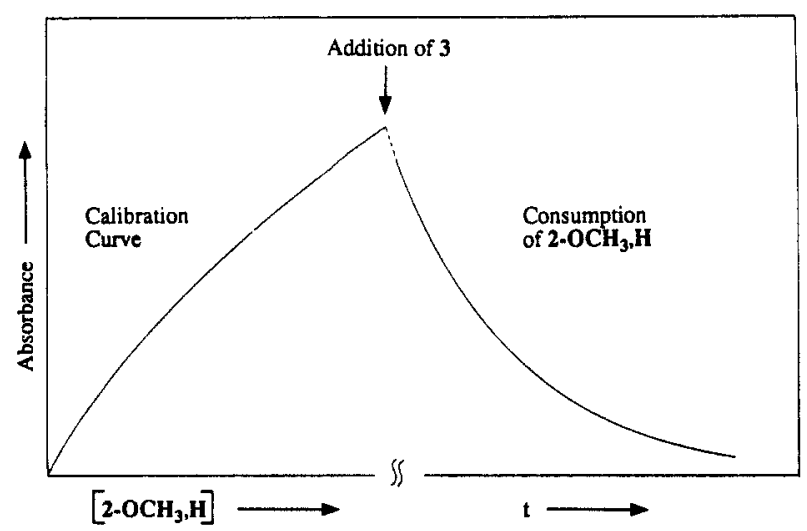

Figure 2. Absorbance $(E)$ during addition of $\mathbf{1}-\mathbf{O C H}_{3}, \mathrm{H}$ to $\mathrm{BCl}_{3} / \mathrm{CH}_{2} \mathrm{Cl}_{2}$ (calibration curve, left) and during the reaction of $2-\mathrm{OCH}_{3}, \mathrm{H} \cdot \mathrm{BCl}_{4}^{-}$with 2-methyl-1-pentene (3) (right).

thus obtained (Figure 2, left) rest on the assumption that the diarylmethyl chlorides 1 become fully ionized in the $\mathrm{BCl}_{3}$ solution, only carbenium ions with $\mathrm{p} K_{\mathrm{R}+}>-10.5$ can be treated in this way. ${ }^{17}$ Though free and paired ions 2 have closely similar UV-vis spectra, their absorptions are not identical, " and the calibration curves are not linear (Figure 2, left).

When the desired concentration of 2 is reached, 1-270 equiv of 3 (neat or concentrated in solution $\mathrm{CH}_{2} \mathrm{Cl}_{2}$ ) are added in one portion, and after a mixing time of $1-1.5 \mathrm{~s}$, acquisition of conductance and absorbance data is started (Figure 2, right). During the reaction, absorbance usually drops to less than $1 \%$ and conductance falls to less than $3 \%$ of the initial value. The connection of the right-hand graphs in Figure 2 with the calibration curves on the left yields a concentration/time correlation, which follows a second-order rate law (eq 2). For the computation, $[3]_{0}-[2]_{0}$ is usually substituted by $\Delta$ (i.e., the excess of alkene employed) to yield eq 3 , which contains the carbenium ion concentration [2] as the only time-dependent variable. ${ }^{156}$ Benzyltriethylammonium chloride is placed into the reaction flask prior to adding $\mathrm{BCl}_{3}$, if the presence of $\mathrm{PhCH}_{2} \mathrm{~N}\left(\mathrm{C}_{2} \mathrm{H}_{5}\right)_{3}{ }^{+} \mathrm{BCl}_{4}^{-}$ is required.

$$
\begin{aligned}
k_{2} t & =\frac{1}{[3]_{0}-[2]_{0}} \ln \frac{[2]_{0} \cdot[3]_{t}}{[3]_{0} \cdot[2]_{t}} \\
k_{2} t & =\frac{1}{\Delta} \ln \frac{[2]_{0}\left([2]_{t}+\Delta\right)}{\left([2]_{0}+\Delta\right)[2]_{t}}
\end{aligned}
$$

Kinetics of the Solvolysis Reactions. The kinetics of the solvolysis reactions were determined as described previously. ${ }^{18}$

2-Methyl-4,4-bis ( $p$-methoxyphenyl)-1-butene (6) (mp 58-59 ${ }^{\circ} \mathrm{C}$, ethanol $/ \mathrm{H}_{2} \mathrm{O}$ ) was prepared via $\mathrm{ZnCl}_{2} / \mathrm{Et}_{2} \mathrm{O}$ catalyzed reaction of 1 $\mathbf{O C H}_{3}, \mathbf{O C H}_{3}$ with isobutene and treatment of the adduct with $\mathrm{KO} t \mathrm{Bu}$ as described for 2-methyl-4,4-diphenyl-1-butene. . $^{\text {sa }}$

3-Chloro-3-methyl-1,1-bis ( $p$-methoxyphenyl)-5,5-bis ( $p$-methylphenyl)pentane (9) (mp 101-102 ${ }^{\circ} \mathrm{C}$, pentane) is formed from 6 and 2- $\mathrm{CH}_{3}, \mathrm{CH}_{3} \cdot \mathrm{BCl}_{4}^{-}$in $\mathrm{CH}_{2} \mathrm{Cl}_{2}$ at $-70^{\circ} \mathrm{C}$. HPLC analysis of the crude reaction product $\left(5-\mu \mathrm{m}\right.$ particles, Nucleosil- $\mathrm{NO}_{2}$ phase, isooctane $/ t$ BuOMe $=80 / 20)$ shows the presence of $0.5-1 \%$ of $10\left(t_{R}=3.54 \mathrm{~min}\right)$ besides $9\left(t_{\mathrm{R}}=8.30 \mathrm{~min}\right)$. Compound $10\left(\mathrm{mp} 115^{\circ} \mathrm{C}\right.$, pentane) was identified by independent synthesis from 8 and $1-\mathrm{CH}_{3}, \mathbf{C H}_{3}$. The NMR spectral data of $\mathbf{9}$ and $\mathbf{1 0}$ are closely similar to those described for 3 chloro-3-methyl-1,1,5,5-tetraphenylpentane. ${ }^{\text {sa }}$

\section{Kinetics of the Reactions of Diarylcarbenium Salts 2 with 2-Methyl-1-pentene (3)}

Complex kinetic equations might a priori be expected, since the formation of 5 from $2 \cdot \mathrm{BCl}_{4}^{-}$and 3 (eq 1) implies two consecutive reactions, each of which might be reversible. Furthermore, the degree of ion pairing $2 \cdot \mathrm{MCl}_{n+1}{ }^{-} \rightleftharpoons 2+\mathrm{MCl}_{n+1}{ }^{-}$is concentration dependent ${ }^{11}$ and might, therefore, influence the observed overall reaction rate.

1. Determination of the Reaction Orders. In a series of ex-

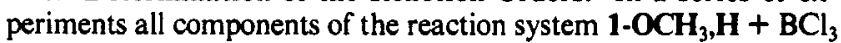
$+\mathbf{3}$ have systematically been varied (Table I). In all cases,

(17) (a) Schade, C.; Mayr, H.; Arnett, E. M. J. Am. Chem. Soc. 1988, 110, 567. (b) Mayr, H.; Schneider, R.; Schade, C. Makromol. Chem., Macromol. Symp. 1988, 13/14,43.

(18) Schade, C.; Mayr, H. Tetrahedron 1988, 44, 5761. 
Table I. Kinetics of the Reaction of p-Methoxydiphenylcarbenium Tetrachloroborate $\left(2 \cdot \mathbf{O C H}_{3}, \mathbf{H} \cdot \mathrm{BCl}_{4}^{-}\right)$with $2 \cdot \mathrm{Methyl}^{-1} \cdot$ pentene $(3)$ in Dichloromethane at $-70^{\circ} \mathrm{C}$

\begin{tabular}{|c|c|c|c|c|c|c|c|c|}
\hline \multirow[b]{2}{*}{ no. } & \multirow[b]{2}{*}[2-\mathrm{OCH}_{3},\mathrm{H}]{$_{0}, \mathrm{~mol} \mathrm{~L}^{-1}$} & \multirow[b]{2}{*}[3]{$_{0}, \mathrm{~mol} \mathrm{~L}^{-1}$} & \multirow[b]{2}{*}[\mathrm{BCl}_{3}]{$_{0},{ }^{a} \mathrm{~mol} \mathrm{~L}^{-1}$} & \multicolumn{2}{|c|}{ conversion, $\%^{b}$} & \multirow[b]{2}{*}{ free ions, $\%^{c}$} & \multicolumn{2}{|c|}{$k_{2}, \mathrm{~L} \mathrm{~mol}^{-1} \mathrm{~s}^{-1}$} \\
\hline & & & & $E$ & $\bar{\kappa}$ & & $E$ & $\kappa$ \\
\hline 1 & $8.6 \times 10^{-3}$ & $1.1 \times 10^{-2}$ & $2.6 \times 10^{-2}$ & 85 & 67 & $75 / 94$ & 26.5 & 25.0 \\
\hline 2 & $8.7 \times 10^{-5}$ & $1.1 \times 10^{-3}$ & $1.3 \times 10^{-2}$ & 93 & & $75 / 97$ & 26.3 & \\
\hline 3 & $8.6 \times 10^{-5}$ & $8.6 \times 10^{-5}$ & $2.3 \times 10^{-2}$ & 58 & 62 & $75 / 86$ & 25.8 & 25.3 \\
\hline 4 & $2.1 \times 10^{-4}$ & $4.2 \times 10^{-3}$ & $5.4 \times 10^{-3}$ & 82 & 76 & $60 / 85$ & 25.3 & 26.5 \\
\hline 5 & $2.2 \times 10^{-4}$ & $4.4 \times 10^{-3}$ & $3.0 \times 10^{-2}$ & 89 & 81 & $59 / 90$ & 27.1 & 25.9 \\
\hline 6 & $2.1 \times 10^{-4}$ & $4.2 \times 10^{-3}$ & $1.0 \times 10^{-1}$ & 86 & 75 & $60 / 88$ & 26.7 & 28.1 \\
\hline 7 & $8.8 \times 10^{-5}$ & $8.9 \times 10^{-3}$ & $5.6 \times 10^{-3}$ & 88 & & $74 / 95$ & 26.0 & \\
\hline 8 & $4.5 \times 10^{-5}$ & $1.2 \times 10^{-2}$ & $2.7 \times 10^{-2}$ & 80 & & $83 / 96$ & 27.8 & \\
\hline 9 & $2.1 \times 10^{-4}$ & $4.2 \times 10^{-3}$ & $1.5 \times 10^{-2}$ & 87 & 84 & $60 / 89$ & 26.2 & 24.8 \\
\hline 10 & $4.1 \times 10^{-3}$ & $1.1 \times 10^{-2}$ & $1.9 \times 10^{-2}$ & 80 & 83 & $19 / 38$ & 26.8 & 26.7 \\
\hline $11^{d}$ & $1.0 \times 10^{-4}$ & $4.1 \times 10^{-3}$ & $1.8 \times 10^{-2}$ & 85 & & $\sim 13^{e}$ & 25.8 & \\
\hline
\end{tabular}

${ }^{a}\left[\mathrm{BCl}_{3}\right]_{0}=$ free $\mathrm{BCl}_{3}$ at $t=0$. ${ }^{b}$ Range evaluated for the determination of $k_{2}$, based on absorbance $(E)$ and conductance $(k)$ measurements. c Percentage of free carbenium ions at $t=0$ and the end of the evaluated range $(E)$ calculated from $K_{\mathrm{D}}=1.9 \times 10^{-4} \mathrm{~mol} \mathrm{~L}^{-1}$ (ref 11 ). din the presence of $1.0 \times 10^{-2} \mathrm{~mol} \mathrm{~L}^{-1}$ benzyltriethylammonium tetrachloroborate. 'Based on the assumption that $K_{\mathrm{D}}$ for $\mathrm{PhCH}_{2} \mathrm{NEt}_{3}{ }^{+} \cdot \mathrm{BCl}_{4}^{-}$is identical with $\mathrm{K}_{\mathrm{D}}$ of $2-\mathrm{OCH}_{3}, \mathrm{H} \cdot \mathrm{BCl}_{4}^{-}$(see ref 11 ).

Scheme II

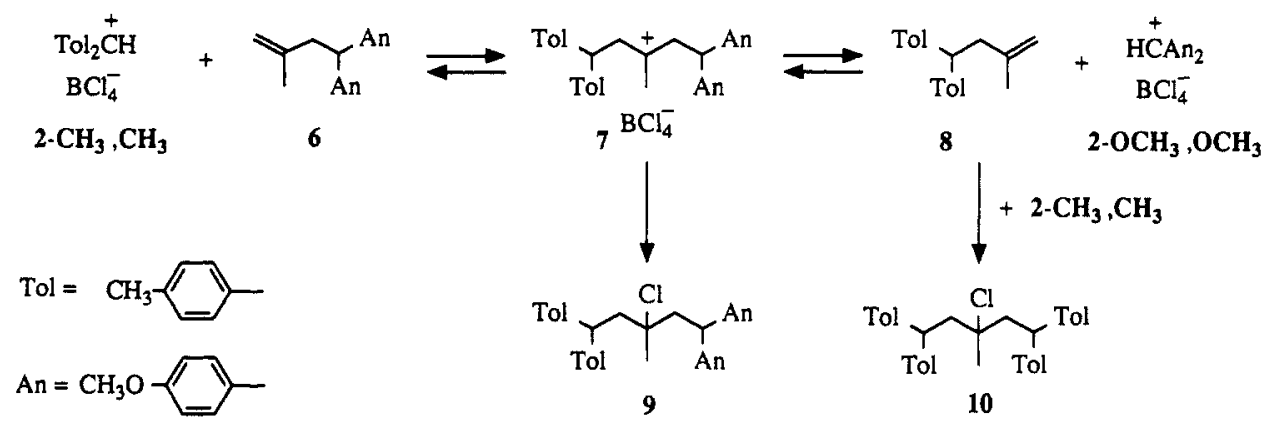

evaluation of absorbance and of conductance data yields the same results. Entries 1-3 (Table I) show that the reaction rates linearly depend on the alkene concentration in the whole range investigated $\left([3]_{0}=1.1 \times 10^{-2}\right.$ to $\left.8.6 \times 10^{-5} \mathrm{~mol} \mathrm{~L}-1\right)$. According to entries $4-6$, the ratio $\left[\mathrm{BCl}_{3}\right]_{0} /[3]_{0}$ does not influence the reaction rate. Even in experiment 7 , the only one with $[3]_{0}>\left[\mathrm{BCl}_{3}\right]_{0}$, the same $k_{2}$ value has been observed, indicating that $\mathrm{BCl}_{3}$ does not form complexes with the olefin 3 . This conclusion, which is in accord with the results of thermochemical studies, ${ }^{17}$ is of great practical importance, since relatively high concentrations of $\mathrm{BCl}_{3}$ are sometimes needed in order to achieve complete ionization of the diarylmethyl chlorides.

The validity of eq 4 over a wide range of carbenium ion concentrations, i.e., the independence of $k_{2}$ of the degree of ion pairing (Table I, column 6) is indicated by entries 8-10. Furthermore, the value of $k_{2}$ remains constant when the reaction is carried out in the presence of $0.01 \mathrm{~mol} \mathrm{~L}^{-1}$ benzyltriethylammonium tetrachloroborate, which reduces the percentage of unpaired ions 2 $\mathbf{O C H}_{3}, \mathbf{H}$ to $13 \%$ (entry 11 ). Equal reactivity of paired and unpaired carbenium ions is indicated by this observation. This conclusion can also be derived from the linearity of the plots according to eq 3 , since the percentage of free ions grows as the reaction proceeds (Table I, column 6 ).

$$
-\mathrm{d}\left[2-\mathrm{OCH}_{3}, \mathrm{H}\right] / \mathrm{d} t=k_{2}\left[2-\mathrm{OCH}_{3}, \mathrm{H}\right][3]
$$

In carbanionic polymerizations, paired and nonpaired ions are known to show considerable reactivity differences. ${ }^{19}$ In contrast, ions and ion pairs are equally reactive in the cationic polymerization of heterocycles. ${ }^{20}$ Investigations of the influence of ion pairing on cationic vinyl polymerization came to the conclusion that free ions are 6-24 times more reactive than ion pairs. ${ }^{21}$ Our observation of equal reactivities of paired and nonpaired ions, therefore, corroborates the view that reactivity differences between

(19) Review: Szwarc, M. In lons and lon Pairs in Organic Reactions; Szwarc, M., Ed.; Wiley: New York, 1974; Vol. II, Chapter 4.

(20) Review: Matyjaszewski, K. J. Macromol. Sci. - Rev. Macromol. Chem. Phys. 1986, C26, 1.

(21) Kunitake, T.; Takarabe, K. Macromolecules 1979, I2, 1067. ions and ion pairs are less pronounced in cationic than in anionic polymerization. ${ }^{20}$

In previous work ${ }^{11}$ we summarized literature data, which report similar values of the dissociation constants $K_{\mathrm{D}}\left(\sim 10^{-4} \mathrm{~mol} \mathrm{~L}^{-1}\right)$ for a large variety of organic salts, e.g. triphenylmethylium, diphenylmethylium, oxonium, sulfonium, and quaternary ammonium salts with complex counterions like $\mathrm{SbCl}_{6}^{-}, \mathrm{BCl}_{4}^{-}, \mathrm{PF}_{6}^{-}$, etc. This behavior is expected from the "sphere in continuum model" for ions of comparable effective size in a particular solvent. ${ }^{22}$ From the relation $\Delta \Delta G^{\circ}=-R T \ln K_{\mathrm{D}}$, one finds that in all these cases, the standard free energy of ion pairs is approximately $14 \mathrm{~kJ} \mathrm{~mol}^{-1}$ lower than $\Delta G^{\circ}$ of the free ions $\left(\mathrm{CH}_{2} \mathrm{Cl}_{2},-70^{\circ} \mathrm{C}\right)$. As this relationship holds for cations of quite dissimilar structural type, it should also be valid for the cations 4 and for the activated complexes yielding the adducts 4 . Consequently, the population ratio (free ions/ion pairs) can be expected to be identical in ground and transition state, and ion pairing does not affect the reaction rates.

2. The Addition Step $(2+3)$ Is Usually Rate-Determining. The constancy of $k_{2}$ in entries 8-11 of Table I proves that the reaction of 2-OCH, $\mathbf{H}$ with 3 is rate-determining, since in case of reversible formation of $4-\mathrm{OCH}_{3}, \mathrm{H}$, an increase of the $\mathrm{BCl}_{4}{ }^{-}$concentration $\left(\left[\mathrm{BCl}_{4}^{-}\right]=\left[2-\mathrm{OCH}_{3}, \mathrm{H}\right]\right.$ for entries 8-10; $\left[\mathrm{BCl}_{4}^{-}\right]=10^{-2} \mathrm{~mol} \mathrm{~L}^{-1}$ for entry 11 ) should result in an acceleration of the overall reaction.

It can be expected, however, that the chance for retroaddition grows with increasing stabilization of the diarylcarbenium ions 2. Therefore, we examined the reaction of $\mathbf{2 - O C H}, \mathbf{O C H}$ with 3 in presence of variable $\mathrm{BCl}_{4}^{-}$concentrations. Only at very low values of $\left[\mathrm{BCl}_{4}^{-}\right]$can a noticeable reduction of the rate constant be observed (Table II, entries 1,2 vs 3-5). This may be explained by slow trapping of the adduct ions 4 . In accord with the assumption of a rate determining carbenium ion addition step and the absence of ion-pairing effects, the same values of $k_{2}$ were obtained when $\mathrm{BClBr}_{3}{ }^{-}$or $\mathrm{B}\left(\mathrm{OCH}_{3}\right) \mathrm{Cl}_{3}^{-}$were used as counterions (entries 6,7 ). The slightly reduced $k_{2}$ value in entry 8 may again indicate a small degree of reversibility at the low concentrations

(22) Denison, J. T.; Ramsey, J. B. J. Am. Chem. Soc. 1955, 77, 2615. 


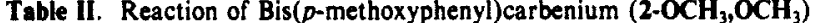
Salts with 2-Methyl-1-pentene (3) in $\mathrm{CH}_{2} \mathrm{Cl}_{2}$ at $-70^{\circ} \mathrm{C}\left([3]_{0}=(3-9) \times\right.$ $10^{-2} \mathrm{~mol} \mathrm{~L}^{-1}$ )

\begin{tabular}{|c|c|c|c|}
\hline no. & {$\left[2-\mathrm{OCH}_{3}, \mathrm{OCH}_{3}\right]_{0}$} & {$\left[\mathrm{MX}_{n}^{-}\right]_{04} \mathrm{~mol} \mathrm{~L}^{-1}$} & $k_{2}, \mathrm{~L} \mathrm{~mol}^{-1} \mathrm{~s}^{-1}$ \\
\hline 1 & $4.38 \times 10^{-5}$ & {$\left[\mathrm{BCl}_{4}^{-}\right]_{0}, 4.38 \times 10^{-5}$} & $\sim 2.1 \times 10^{-20}$ \\
\hline 2 & $4.34 \times 10^{-5}$ & {$\left[\mathrm{BCl}_{4}^{-}\right]_{0}, 4.60 \times 10^{-4}$} & $2.64 \times 10^{-2 b}$ \\
\hline 3 & $4.30 \times 10^{-5}$ & {$\left[\mathrm{BCl}_{4}^{-}\right]_{0}, 1.03 \times 10^{-3}$} & $2.92 \times 10^{-2 b}$ \\
\hline 4 & $4.38 \times 10^{-5}$ & {$\left[\mathrm{BCl}_{4}^{-}\right]_{0}, 6.70 \times 10^{-3}$} & $2.86 \times 10^{-2 b}$ \\
\hline 5 & $4.38 \times 10^{-5}$ & {$\left[\mathrm{BCl}_{4}^{-}\right]_{0}, 1.47 \times 10^{-2}$} & $2.97 \times 10^{-2 b}$ \\
\hline 6 & $8.70 \times 10^{-4}$ & 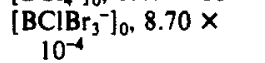 & $(2.70 \pm 0.14) \times 10^{-2 c}$ \\
\hline 7 & $7.01 \times 10^{-4}$ & $\begin{array}{l}{\left[\mathrm{B}\left(\mathrm{OCH}_{3}\right) \mathrm{Cl}_{3}^{-}\right]_{0},} \\
7.01 \times 10^{-4}\end{array}$ & $(2.81 \pm 0.12) \times 10^{-2 d}$ \\
\hline 8 & $4.22 \times 10^{-5}$ & {$\left[\mathrm{SnCl}_{5}^{-}\right]_{0}, 4.22 \times 10^{-5}$} & $(2.48 \pm 0.12) \times 10^{-2 a, e}$ \\
\hline
\end{tabular}

${ }^{a} k_{2}$ calculated from initial slope. ${ }^{b}$ In the presence of benzyltriethylammonium tetrachloroborate; its concentration is the difference between columns 3 and 2. 'Ionization of $\mathbf{1 - O C H}, \mathbf{O C H}_{3}$ with $\mathrm{BBr}_{3}$; two experiments. ${ }^{d}$ Ionization of $\left(p-\mathrm{CH}_{3} \mathrm{O}-\mathrm{C}_{6} \mathrm{H}_{4}\right)_{2} \mathrm{CHOCH}_{3}$ with $\mathrm{BCl}_{3}$; three experiments. - Ionization of $1-\mathrm{OCH}_{3}, \mathrm{OCH}_{3}$ with $\mathrm{SnCl}_{4}$; three experiments.

\section{Scheme III}

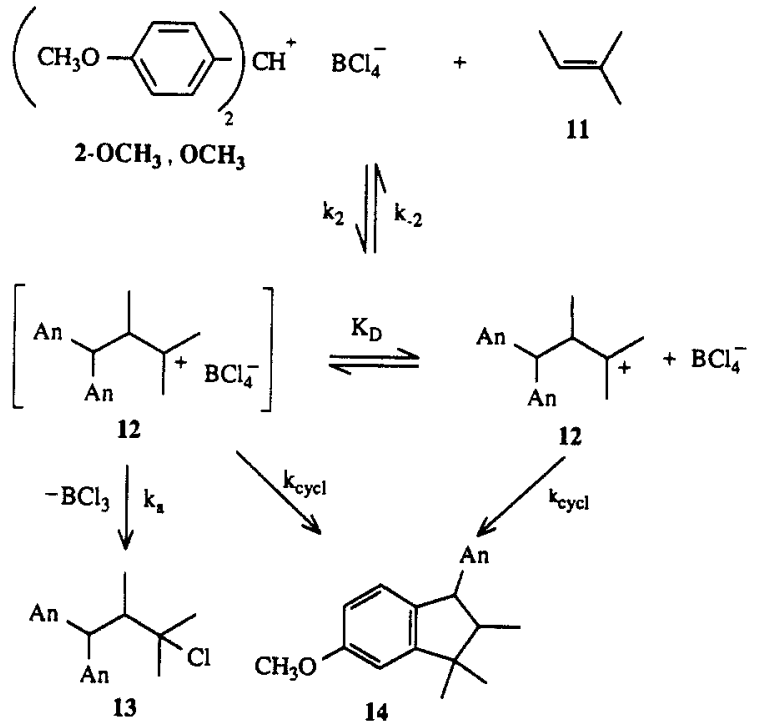

used for this reaction (low solubility of $\mathbf{2 -} \mathbf{O C H}_{3}, \mathbf{O C H}_{3} \cdot \mathrm{SnCl}_{5}{ }^{-}$).

Our conclusion that reversibility of the addition step does not play an important role even in reactions of 1,1-dialkylated alkenes with $\mathbf{2 -} \mathbf{O C H}_{3}, \mathbf{O C H}$, the best stabilized carbenium ion of this series, is corroborated by the experiment involving Scheme II. ${ }^{23}$

When $2-\mathrm{CH}_{3}, \mathrm{CH}_{3} \cdot \mathrm{BCl}_{4}{ }^{-}$was combined with the alkene 6 , the additon product 9 was formed almost exclusively with only a small trace of 10 present. From HPLC analysis a ratio $\mathbf{9 / 1 0}=(130$ \pm 20 ): 1 was obtained. Therefore, we can conclude that a very small percentage of 7 cleaves into 8 and $2-\mathbf{O C H}_{3}, \mathbf{O C H}_{3}$ since any 8 produced would immediately be trapped by $2-\mathbf{C H}_{3}, \mathbf{C H}_{3}$ to give 10.

The effect of anion concentration has been studied in greater detail for reactions of diarylcarbenium tetrachloroborates with 2-methyl-2-butene (11), which give mixtures of regular addition products and of indans (e.g., 13 and 14, Scheme III). Just as for the reactions with 2-methyl-1-pentene (3), the rates of the reactions of $2-\mathrm{CH}_{3}, \mathrm{CH}_{3}, \mathbf{2 - O} \mathrm{Ph}, \mathrm{H}$, and $2-\mathrm{OCH}_{3}, \mathrm{H}$ with 2methyl-2-butene (11) do not depend on the concentration of $\mathrm{BCl}_{4}^{-}$ in the concentration range investigated $\left(5 \times 10^{-5}\right.$ to $\left.10^{-2} \mathrm{~mol} \mathrm{~L}^{-1}\right)$, again indicating $2+11$ to be the rate-determining step. For the reaction of $2-\mathrm{OCH}_{3}, \mathrm{CH}_{3} \cdot \mathrm{BCl}_{4}^{-}$with 11 , the rate decreases by $25 \%$ when $\left[2-\mathrm{OCH}_{3}, \mathrm{CH}_{3} \cdot \mathrm{BCl}_{4}{ }^{-}\right]$is reduced from $2 \times 10^{-2}$ to $5 \times 10^{-5}$ $\mathrm{mol} \mathrm{L} \mathrm{L}^{-1}{ }^{17 \mathrm{~b}}$

A greater dependence on anion concentration is observed for the reaction of 11 with $2-\mathrm{OCH}_{3}, \mathbf{O C H}_{3}$. As shown in Figure 4,

(23) An analogous experiment has been used to prove the irreversibility of the $\mathrm{ZnCl}_{2}$ catalyzed additions of diphenylmethyl chloride to 1,1-dialkylethylenes (ref 5a).

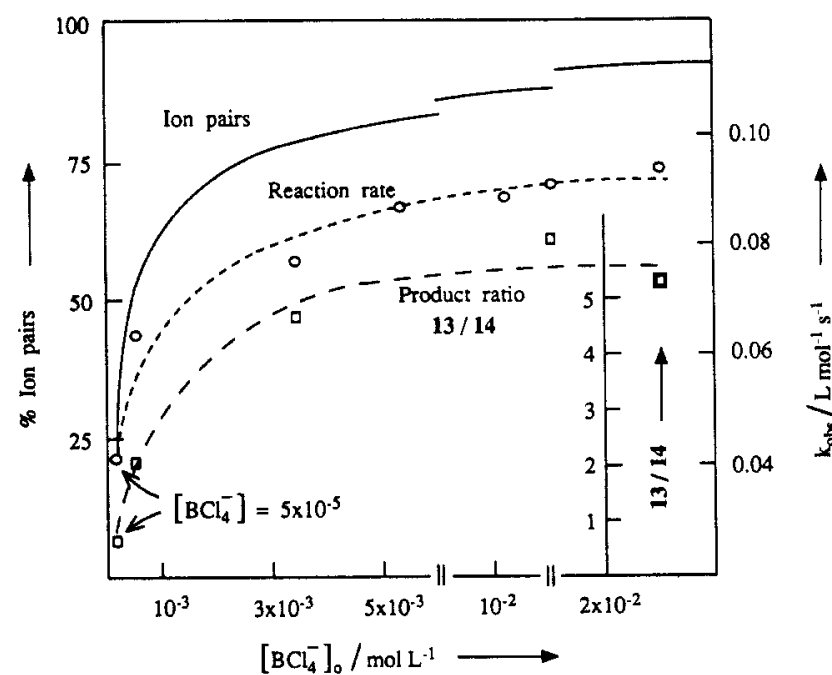

Figure 3. Influence of $\left[\mathrm{BCl}_{4}^{-}\right]$on the degree of ion-pairing (solid line, calcd for $K_{\mathrm{D}}=2 \times 10^{-4} \mathrm{~mol} \mathrm{~L}^{-1}$ ), observed rate constant (circles, from initial slopes), and product ratio (squares) for the reaction of 2 $\mathrm{OCH}_{3}, \mathrm{OCH}_{3} \cdot \mathrm{BCl}_{4}^{-}$with 2-methyl-2-butene (11)

the reaction rate increases by more than a factor of 2 when $\left[\mathrm{BCl}_{4}^{-}\right]_{0}$ is increased from $5 \times 10^{-5}$ to $5 \times 10^{-3} \mathrm{~mol} \mathrm{~L}^{-1}$, but a further increase of $\left[\mathrm{BCl}_{4}^{-}\right]$hardly affects the observed reaction rates (Figure 3).

An explanation for these observations is given by Scheme III, which shows that the formation of the linear adduct 13 has to proceed through ion pairs, while 14 may arise from free or paired 12. For $\left[\mathrm{BCl}_{4}^{-}\right]>5 \times 10^{-3} \mathrm{~mol} \mathrm{~L}-1$, ion pairing is almost complete $(>80 \%)$, and a further conspicuous acceleration of the reaction by increasing the concentration of $\mathrm{BCl}_{4}^{-}$is not possible. Scheme III also explains why the product ratio $13 / 14$ grows with $\left[\mathrm{BCl}_{4}^{-}\right]$ in the concentration range $5 \times 10^{-5}$ to $5 \times 10^{-3} \mathrm{~mol} \mathrm{~L}^{-1}$ and is only slightly affected by higher $\mathrm{BCl}_{4}^{-}$concentrations when ionpairing is almost complete. In accord with this interpretation, addition of the weak chloride donor $\mathrm{SbCl}_{6}^{-}\left(5 \times 10^{-3} \mathrm{~mol} \mathrm{~L}^{-1}\right)$ to a solution of $\mathbf{2 -} \mathbf{O C H}_{3}, \mathbf{O C H}_{3} \cdot \mathrm{BCl}_{4}^{-}\left(5 \times 10^{-5} \mathrm{~mol} \mathrm{~L}^{-1}\right)$ does not affect the reaction rate.

3. Activation Parameters for the Reactions of Diarylcarbenium Tetrachloroborates with 2-Methyl-1-pentene. Since the addition

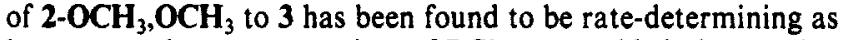
long as very low concentrations of $\mathrm{BCl}_{4}{ }^{-}$are avoided, the reaction rates observed for the other carbenium ions listed in Table III must also correspond to the rates of the addition steps. As expected, reactivity increases with decreasing electron releasing ability of the para substituents of 2-X,Y (Table III). Table III furthermore shows that variation of the para substituents only affects $\Delta H^{*}$, while $\Delta S^{*}$ remains almost constant. From the three entries for $2-\mathbf{O C H}_{3}, \mathrm{H}$ one sees that $\Delta G^{*}\left(-70^{\circ} \mathrm{C}\right)$ is unaffected by a variation of the ion strength (cf. Section 1). For $\Delta H^{*}$ and $\Delta S^{*}$, however, a slight dependence on ion concentration was found; this may be within experimental uncertainty.

4. Solvent Dependence of the Reaction Rates. The bis $(p$ methoxy)-substituted benzhydryl cation was selected for the investigation of solvent effects, since this system promised to be fully ionized in less polar solvents as well. However, even with 2$\mathbf{O C H}, \mathbf{O C H}_{3}$, the choice of solvents turned out to be rather limited. In nonpolar solvents, e.g. toluene, $\mathrm{CS}_{2}$, pentane, $\mathrm{CCl}_{4}$, and tri-

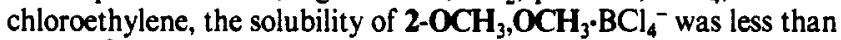
$5 \times 10^{-5} \mathrm{~mol} \mathrm{~L}^{-1}$, and in donor solvents, like THF or acetonitrile, complexation between solvent and $\mathrm{BCl}_{3}$ prevented a complete ionization of $\mathbf{1 - O C H}, \mathrm{OCH}_{3}$. Kinetic investigations were finally carried out in the five solvents listed in Table IV. In order to avoid the reversibility of the addition step (see above), the reactions were studied in the presence of benzyltriethylammonium tetrachloroborate.

Since the rate-determining step involves the formation of a mono-positively charged ion (4) from a mono-positively charged (2) and a neutral precursor (3), so that charge is neither generated 
Table III. Rate Constants $k_{2}$ (Measured at $-70^{\circ} \mathrm{C}$ ) and Activation Parameters for the Reaction of Diarylcarbenium Tetrachloroborates with 2-Methyl-1-pentene ${ }^{a}$

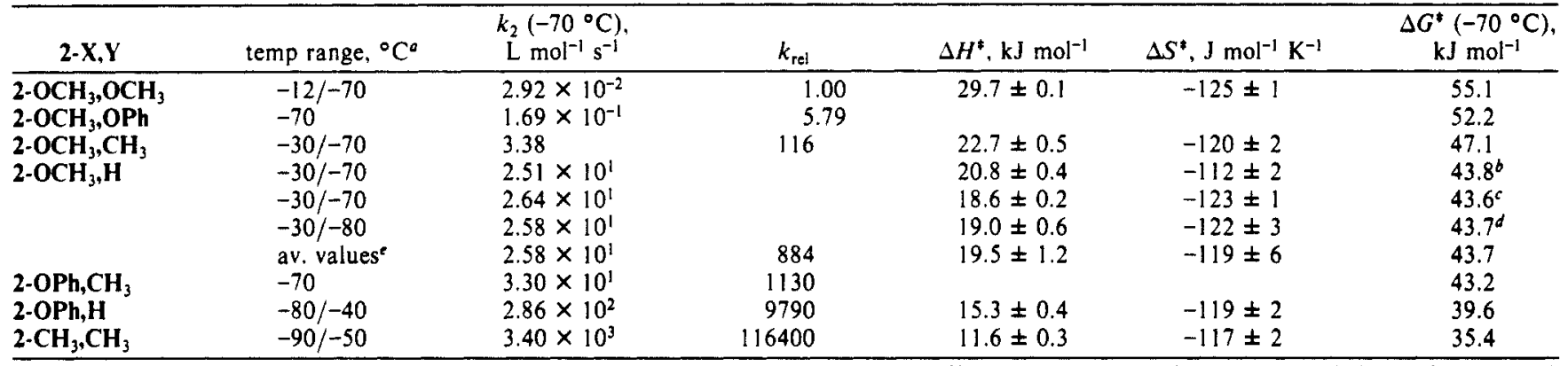

${ }^{a}$ For the determination of the activation parameters at least four experiments at different temperatures have been carried out; $k_{2}\left(-70{ }^{\circ} \mathrm{C}\right)$ obtained by regression analysis if experiments at different temperatures are available. ${ }^{b}\left[2-\mathrm{OCH}_{3}, \mathbf{H} \cdot \mathrm{BCl}_{4}^{-}\right]_{0}=2 \times 10^{-4} \mathrm{~mol} \mathrm{~L}^{-1}{ }^{c}\left[2-\mathrm{OCH}_{3}, \mathrm{H}^{-} \mathrm{BCl}_{4}^{-}\right]_{0}$

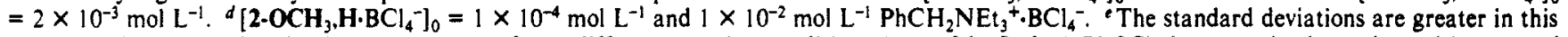
line since the averaged activation parameters refer to different reaction conditions (see ref $b-d) ; k_{2}\left(-70^{\circ} \mathrm{C}\right.$ ), however, is almost insensitive toward variation of the ion strength.

Table IV. Reaction of the Bis ( $p$-methoxyphenyl)carbenium $\left(2-\mathbf{O C H}_{3}, \mathbf{O C H}\right)$ Tetrachloroborate with 2-Methyl-1-pentene (3) in Various Solvents ${ }^{a}$

\begin{tabular}{lccccccc}
\hline \multicolumn{1}{c}{ solvent } & $\epsilon^{b}$ & $E_{\mathrm{T}}(30)^{c}$ & temp range ${ }^{\circ} \mathrm{C}$ & $\Delta H^{*}, \mathrm{~kJ} \mathrm{~mol}^{-1}$ & $\Delta S^{*}, \mathrm{~J} \mathrm{~mol}^{-1} \mathrm{~K}^{-1}$ & $\begin{array}{c}\Delta G^{*}\left(-30^{\circ} \mathrm{C}\right), \\
\mathrm{kJ} \mathrm{mol}^{-1}\end{array}$ & $\begin{array}{c}k_{2}\left(-30^{\circ} \mathrm{C}\right), \\
\mathrm{kJ} \mathrm{mol}^{-1}\end{array}$ \\
\hline $\mathrm{CHCl}_{3}$ & 4.81 & 39.1 & $-10 /-50$ & 32.9 & -113 & 60.4 & 0.543 \\
$\mathrm{CH}_{2} \mathrm{Cl}_{2}$ & 8.9 & 40.7 & $-12 /-70$ & 29.7 & -125 & 60.1 & 0.632 \\
$\left(\mathrm{CH}_{2} \mathrm{Cl}_{2}\right.$ & 10.37 & 41.3 & $10 /-31$ & 28.6 & -126 & 59.2 & 0.958 \\
$\mathrm{CH}_{3}-\mathrm{CH}_{2}-\mathrm{NO}_{2}$ & $28.06^{d}$ & 43.6 & $-31 /-70$ & 30.0 & -116 & 58.2 & 1.56 \\
$\mathrm{CH}_{3}-\mathrm{NO}_{2}$ & 35.94 & 46.3 & $9 /-21$ & 27.3 & -123 & 57.2 & 2.63 \\
\hline
\end{tabular}

${ }^{a}\left[2-\mathrm{OCH}_{3}, \mathrm{OCH}_{3}\right]_{0}=10^{-4} \mathrm{~mol} \mathrm{~L}^{-1} ;[3]_{0}=3 \times 10^{-3}$ to $2 \times 10^{-2} \mathrm{~mol} \mathrm{~L}^{-1}$. ${ }^{b}$ Dielectric constant at $25^{\circ} \mathrm{C} ; \mathrm{ref} 24 .{ }^{c} E_{\mathrm{T}}(30) / \mathrm{kcal} / \mathrm{mol} ; \mathrm{ref} 24$. d 30 ${ }^{\circ} \mathrm{C}$, ref 16, p 576.

nor destroyed in the rate-determining step, the rate constants increase only slightly with the solvent polarity. While the correlation between $\log k_{2}$ and $\epsilon$ is rather poor, a fair correlation with the solvent polarity parameter $E_{\mathrm{T}}(30)^{24}$ was found: $\log k_{2}(-30$ $\left.{ }^{\circ} \mathrm{C}\right)=0.0995 E_{\mathrm{T}}-4.17(r=0.986)$.

Chlorinated hydrocarbons are typical solvents for carbocationic polymerizations: The first three entries of Table IV indicate that the propagation rate constants in cationic polymerization can be expected to be almost identical in solvents of that type. ${ }^{25}$

5. Kinetic Isotope Effects. The $\alpha$-deuterium-labeled benzhydryl

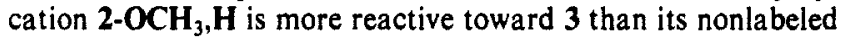
analogue $\left(k_{\mathrm{H}} / k_{\mathrm{D}}=0.80\right)$. Secondary $\alpha-\mathrm{D}$ effects of similar

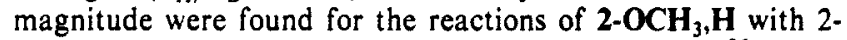
methyl-2-butene $(0.79)$ and allyltrimethylsilane $(0.79),{ }^{26}$ closely resembling the $k_{\mathrm{H}} / k_{\mathrm{D}}$ values observed for the mechanistically related additions of a $\mu$-methylidyne complex across alkenes. ${ }^{27}$

Secondary kinetic isotope effects $k_{\mathrm{H}} / k_{\mathrm{D}}$ are generally smaller than unity if deuterium is located at a carbon that undergoes a change from $\mathrm{sp}^{2}$ to $\mathrm{sp}^{3}$ hybridization, e.g., in additions to the $\mathrm{CC}$ double bond of alkenes ${ }^{28}$ or to the carbonyl bond of aldehydes. ${ }^{29}$ Equilibrium secondary $\alpha$ isotope effects have been determined for the ionization of diarylmethanols in $\mathrm{H}_{2} \mathrm{SO}_{4}$ (eq 5). The isotope effects on $K_{\mathrm{R}^{+}}$decrease from $\left(K_{\mathrm{R}^{+}, \mathrm{H}} / K_{\mathrm{R}^{+}, \mathrm{D}}=0.85\right)$ for $2-\mathrm{OCH}_{3}, \mathrm{H}$ to $\left(K_{\mathrm{R}^{+}, \mathrm{H}} / K_{\mathrm{R}^{+}, \mathrm{D}}=0.77\right)$ for $2-\mathrm{H}, \mathrm{H}^{30}$

$$
\mathrm{Ar}_{2} \mathrm{CD}^{+}+\mathrm{H}_{2} \mathrm{O} \stackrel{\kappa_{\mathrm{R}}^{+}}{\rightleftharpoons} \mathrm{Ar}_{2} \mathrm{CDOH}+\mathrm{H}^{+}
$$

Equilibrium isotope effects for the formation of cyanohydrins from benzaldehydes (carbon group entering) are of essentially the same magnitude. ${ }^{31}$ Comparison of these numbers with the $k_{\mathrm{H}} / k_{\mathrm{D}}$

(24) Reichardt, C. Solvents and Solvent Effects in Organic Chemistry, 2nd ed.; VCH Verlagsgesellschaft: Weinheim, 1988

(25) For a discussion see ref $2 b, p$ 275-276.

(26) Details of these reactions are reported: Mayr, H.; Schneider, R.; Grabis, U. J. Am. Chem. Soc., third of three papers in this issue.

(27) Casey, C. P.; Meszaros, M. W.; Fagan, P. J.; Bly, R. K.; Marder, S. R.; Austin, E. A. J. Am. Chem. Soc. 1986, 108, 4043 .

(28) Hoffmann, R. W. Aufklärung von Reaktionsmechanismen; Georg Thieme: Stuttgart, 1976; p 75 .

(29) Willi, A. V. Isotopeneffekte bei chemischen Reaktionen; Georg Thieme: Stuttgart, 1983: pp 80, 121.

(30) Mocek, M. M.; Stewart, R. Can. J. Chem. 1963, 4l, 1641.
Table V. Rate Constants for the Reaction of $\alpha$-Deuterio- $p$-methoxydiphenylcarbenium Tetrachloroborate $[(1.7 \pm$ $\left.0.1) \times 10^{-4} \mathrm{~mol} \mathrm{~L}-1\right]$ with some Nucleophiles in $\mathrm{CH}_{2} \mathrm{Cl}_{2}$ at $-70.0^{\circ} \mathrm{C}$

\begin{tabular}{|c|c|c|c|c|}
\hline nucleophile & $\begin{array}{c}\text { [nucleophile] } \\
10^{-4} \mathrm{~mol} \mathrm{~L}^{-1}\end{array}$ & $\begin{array}{c}k_{2}(\mathrm{D}), \\
\mathrm{L} \mathrm{mol}^{-1} \mathrm{~s}^{-1}\end{array}$ & $\begin{array}{c}k_{2}(\mathrm{H}), \\
\mathrm{L} \mathrm{mol}^{-1} \mathrm{~s}^{-1}\end{array}$ & $k_{\mathrm{H}} / k_{\mathrm{D}}$ \\
\hline & $\begin{array}{l}11.0 \\
27.4 \\
7.67 \\
\text { average }\end{array}$ & $\begin{array}{l}32.2 \\
32.2 \\
32.9 \\
32.4\end{array}$ & $25.8^{a}$ & 0.80 \\
\hline $\mathrm{SiMe}_{3}$ & $\begin{array}{l}13.7 \\
10.8 \\
7.72 \\
5.47 \\
\text { average }\end{array}$ & $\begin{array}{l}232 \\
233 \\
242 \\
242 \\
237\end{array}$ & $187^{b}$ & 0.79 \\
\hline & $\begin{array}{l}11.0 \\
8.24 \\
6.59 \\
5.48 \\
\text { average }\end{array}$ & $\begin{array}{l}307 \\
315 \\
308 \\
325 \\
314\end{array}$ & $247^{b}$ & 0.79 \\
\hline
\end{tabular}

'This work. ${ }^{b}$ Reference 26.

values presented in Table $\mathrm{V}$ leads to the conclusion that the rehybridization of the carbenium center of $2-\mathrm{OCH}_{3}, \mathrm{H}\left(\mathrm{sp}^{2} \rightarrow \mathrm{sp}^{3}\right)$ is far advanced in the transition state. Support for this interpretation comes from the rate equilibrium relationships discussed in Section VI.3.

\section{Energy Profiles for the $\mathrm{BCl}_{3}$-Promoted Reactions of Diarylmethyl Chlorides (1) with 2-Methyl-1-pentene (3)}

In the reaction sequence (1), the rate-determining step $2+3$ $\rightarrow 4$ is preceded by the ionization step $1 \rightarrow 2$ and succeeded by the ion combination step $4 \rightarrow 5$. Whereas the first step can be investigated directly, indirect methods are needed to obtain information about the energy of the adduct cations 4.

1. Ionization of the Diarylmethyl Chlorides. Calorimetric and equilibrium studies ${ }^{17,18}$ have been carried out to characterize the thermodynamics of the reactions of diarylmethyl chlorides $(\mathbf{1 - X}, \mathbf{Y})$

(31) (a) Young, P. R.; McMahon, P. E. J. Am. Chem. Soc. 1979, 101, 4678. (b) Amaral, L. do; Bull, H. G.; Cordes, E. H. J. Am. Chem. Soc. 1972, 94. 7579 . 
Table VI. First-Order Ionization Rate Constants for Oxy-Substituted Diarylmethyl Chlorides $\left(\mathrm{CH}_{2} \mathrm{Cl}_{2}, \mathrm{BCl}_{3}\right)$

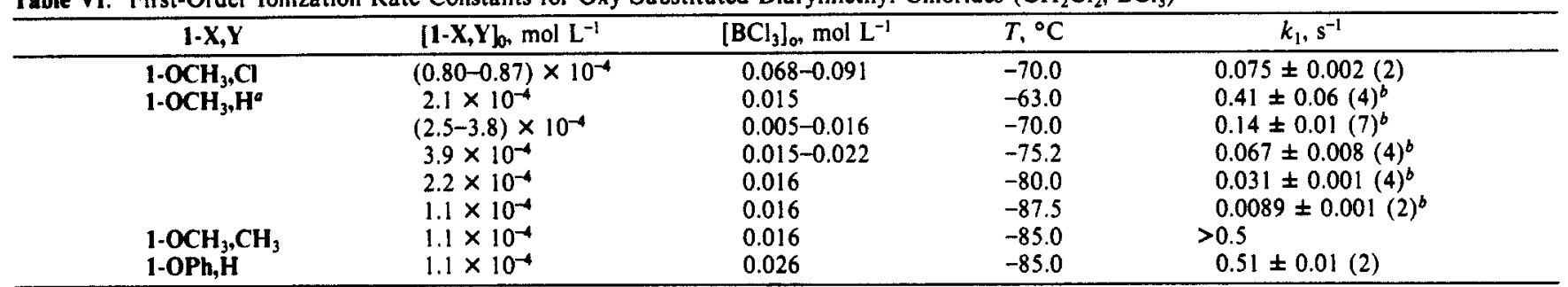

$a \Delta H^{*}=48.7 \pm 0.7 \mathrm{~kJ} \mathrm{~mol}^{-1} ; \Delta S^{*}=-18 \pm 3 \mathrm{~J} \mathrm{~mol}^{-1} \mathrm{~K}^{-1}$. ${ }^{b}$ The number of independent experiments is smaller than the number in parentheses, since in many cases absorbance and conductance data from the same experiment have been included.

with $\mathrm{BCl}_{3}$. The rates of ionization are usually very high, and the formation of most of the salts $\mathbf{2 - X}, \mathbf{Y} \cdot \mathrm{BCl}_{4}^{-}$is complete within 1 $s$, the time needed for mixing $1-\mathrm{X}, \mathrm{Y}$ with $\mathrm{BCl}_{3}$. The ionization of $\mathbf{1 - O C H}, \mathbf{H}$ is somewhat slower, however, and can be recorded with the kinetic setup described in Figure 1. Again, absorbance and conductance data yield the same rate constants. When an

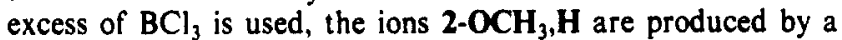
first-order reaction, i.e., the rate depends linearly on $\left[1-\mathbf{O C H}_{3}, \mathbf{H}\right]$ and is independent of $\left[\mathrm{BCl}_{3}\right]$. The reaction order and the fact

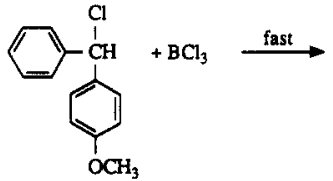

$1-\mathrm{OCH}_{3}, \mathrm{H}$

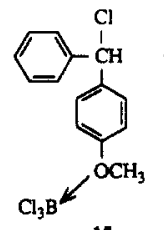

15

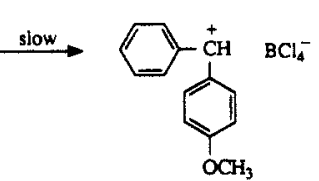

$2-\mathrm{OCH}_{3}, \mathrm{H}$ that $1-\mathrm{OCH}_{3}, \mathrm{H}$ ionizes more slowly than $\mathbf{1 -} \mathrm{CH}_{3}, \mathrm{CH}_{3}$, though the latter reaction is less exergonic, suggest the rapid formation of the complex 15, which then decomposes in a first-order reaction (Table VI). If one assumes the $\mathrm{B}-\mathrm{O}$ bond to be of similar strength in the complexes of $\mathrm{BCl}_{3}$ with $1-\mathbf{O C H}_{3}, \mathrm{Cl}$ and $1-\mathrm{OCH}_{3}, \mathrm{CH}_{3}$, one can rationalize the relative rates of ionization $\left(1-\mathrm{OCH}_{3}, \mathrm{Cl}<\right.$

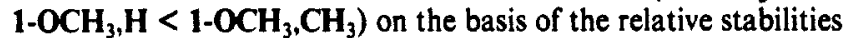
of the resulting carbenium ions 2. The fast ionization of 1-OPh,H is explained by the lower tendency of the diaryl ether oxygen to associate with $\mathrm{BCl}_{3}$, and $\mathbf{1 -} \mathbf{C H}_{3}, \mathbf{C H}_{3}$ is assumed not to form any stable complex with $\mathrm{BCl}_{3}$. This interpretation is in accord with our previous report that methoxy-substituted benzene derivatives are complexed by $\mathrm{BCl}_{3}$ in $\mathrm{CH}_{2} \mathrm{Cl}_{2}\left(\Delta H_{\mathrm{c}}=-45.3 \pm 1.8 \mathrm{~kJ} \mathrm{~mol}^{-1}\right)$ while the corresponding methyl-substituted compounds do not interact with $\mathrm{BCl}_{3}$ in $\mathrm{CH}_{2} \mathrm{Cl}_{2}{ }^{17 a}$

Dialkyl ethers and their complexes with $\mathrm{BCl}_{3}$ have been observed as separate species by low-temperature ${ }^{1} \mathrm{H}$ NMR spectroscopy, while averaged signals were noticed at room temperature. ${ }^{32}$ In contrast, we observed only averaged resonances when a mixture of anisole and of its complex with $\mathrm{BCl}_{3}$ was studied in $\mathrm{CD}_{2} \mathrm{Cl}_{2}$ at $-70^{\circ} \mathrm{C}\left(200 \mathrm{MHz},{ }^{1} \mathrm{H}\right.$ NMR $)$. The rapid exchange indicated by this finding corroborates our suggestion that the

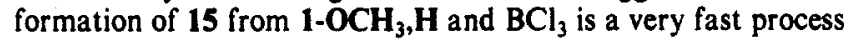
(probably diffusion controlled).

2. Ionization of the Addition Products 5. Since the carbenium ions 4 are short-lived intermediates, which are produced after the rate-determining step in the reaction sequence (eq 1), their energy cannot be derived from the kinetics of the reaction of 2 with 3 Therefore, we have attacked this problem from the product side. As the ionization of 5 by $\mathrm{BCl}_{3}$ is endergonic in $\mathrm{CH}_{2} \mathrm{Cl}_{2}$ and cannot easily be studied by equilibrium measurements, the energy of cations 4 relative to 5 was derived from solvolytic experiments. Arnett has demonstrated that the ionization enthalpies $\left(\Delta H_{i}\right)$ of secondary and tertiary alkyl and arylalkyl chlorides in superacidic media are linearly correlated with their ethanolysis rate constants $\left(25^{\circ} \mathrm{C}\right.$, eq 6)..$^{33}$ The analogous correlation between the ionization

(32) (a) Deters, J. F.; McCusker, P. A.; Pilger, R. C. J. Am. Chem. Soc. 1968, 90. 4583. (b) Gore, E.; Danyluk, S. S. J. Phys. Chem. 1965, 69, 89

(33) (a) Arnett, E. M.; Petro, C.; Schleyer, P. v. R. J. Am. Chem. Soc 1979, 101, 522. (b) Arnett, E. M.; Hofelich, T. C. J. Am. Chem. Soc. 1983 105,2889 (eq 4 in this article lacks a "minus" sign).
Table VII. Solvolysis Rate Constants of the Addition Products 5 in $80 \% \mathrm{EtOH} / \mathrm{H}_{2} \mathrm{O}$ at $50^{\circ} \mathrm{C}$

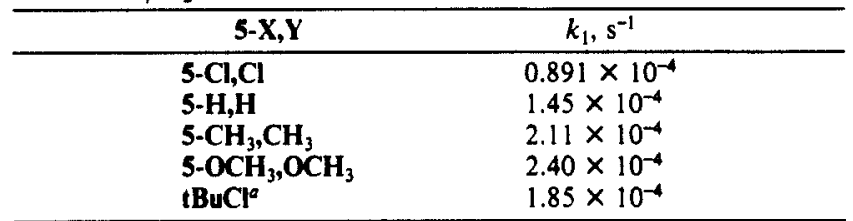

a Reference 34

free energies of diarylmethyl chlorides in $\mathrm{CH}_{2} \mathrm{Cl}_{2} / \mathrm{BCl}_{3}$ and the corresponding ethanolysis rate constants $\left(25^{\circ} \mathrm{C}\right.$, eq 7$)$ has a similar slope. ${ }^{18}$ As eq 6 was found to include diarylmethyl chlorides as well as tertiary alkyl chlorides, an analogous scope can be expected for eq 7 , and this equation is used to calculate $\Delta G_{i}^{\circ}\left(\mathrm{CH}_{2} \mathrm{Cl}_{2}, \mathrm{BCl}_{3}\right)$ from the ethanolysis rate constants of compounds 5 . According

$$
\Delta H_{\mathrm{i}}\left(\mathrm{RCl}, \mathrm{SO}_{2} \mathrm{ClF} / \mathrm{SbF}_{5}\right) / \mathrm{kJ} \mathrm{mol}^{-1}=-6.78\left(\log k_{\text {solv }}\right)-157
$$

$\Delta G_{\mathrm{i}}^{\circ}\left(\mathrm{CH}_{2} \mathrm{Cl}_{2}, \mathrm{BCl}_{3},-70^{\circ} \mathrm{C}\right) / \mathrm{kJ} \mathrm{mol}^{-1}=$

$$
-7.65\left(\log k_{\text {solv }}\right)-19.8(7)^{18}
$$

to Table VII, the solvolysis rates of the tertiary alkyl chlorides 5 closely resemble that of tert-butyl chloride. The slight dependence of $k_{1}$ on the nature of the p-substituents will be discussed later. From the $m$ value ${ }^{34}$ and the activation parameters determined for compounds 16 in aqueous ethanol, ${ }^{96}$ one derives a factor of $2.52 \times 10^{-3}$ which converts the $k_{1}$ values of compounds 5 (Table VII) into the corresponding ethanolysis rates $\left(25^{\circ} \mathrm{C}\right)$. From these data, $\Delta G_{i}{ }^{\circ}$ for the reactions (8) is calculated to be $+29.4(\mathrm{X}=$ $\mathrm{Y}=\mathrm{H}),+28.2\left(\mathrm{X}=\mathrm{Y}=\mathrm{CH}_{3}\right)$, and $+27.8 \mathrm{~kJ} \mathrm{~mol}^{-1}(\mathrm{X}=\mathrm{Y}$ $=\mathrm{OCH}_{3}$ ). While the differences between these numbers are

$$
\begin{gathered}
\mathrm{Ar}_{2} \mathrm{CHCH}_{2} \mathrm{C}\left(\mathrm{CH}_{3}\right)_{2} \mathrm{Cl} \\
5-\mathrm{X}, \mathrm{Y}+\mathrm{BCl}_{3} \frac{\mathrm{CH}_{2} \mathrm{Cl}_{2}}{-70^{\circ} \mathrm{C}} 4-\mathrm{X}, \mathrm{Y} \cdot \mathrm{BCl}_{4}^{-}
\end{gathered}
$$

estimated to be accurate within $\pm 0.2 \mathrm{~kJ} \mathrm{~mol}^{-1}$, an uncertainty of $\pm(6-8) \mathrm{kJ} \mathrm{mol}^{-1}$ is assumed for their absolute values. Comparison of eqs 9 and 10 shows the correct order of magnitude for these numbers:

$$
\begin{gathered}
\mathrm{Ph}_{2} \mathrm{CHOH} \frac{\mathrm{SbF}_{3} / \mathrm{FSO}_{3} \mathrm{H} / \mathrm{SO}_{2} \mathrm{ClF}}{\Delta H_{\mathrm{r}}=-164.5 \pm 2.9 \mathrm{~kJ} \mathrm{~mol} l^{-1}} \mathrm{Ph}_{2} \mathrm{CH}^{+} \quad(9)^{33 \mathrm{~b}} \\
\left(\mathrm{CH}_{3}\right)_{3} \mathrm{COH} \frac{\mathrm{SbF}_{3} / \mathrm{FSO}_{3} \mathrm{H} / \mathrm{SO}_{2} \mathrm{ClF}}{\Delta H_{\mathrm{r}}=-148.5 \pm 1.7 \mathrm{~kJ} \mathrm{~mol} l^{-1}}\left(\mathrm{CH}_{3}\right)_{3} \mathrm{C}^{+}(10)^{33 \mathrm{~b}}
\end{gathered}
$$

Arnett found the ionization of diphenylmethanol in superacidic media to be $16 \mathrm{~kJ} \mathrm{~mol}^{-1}$ more exothermic than the ionization of tert-butyl alcohol (eqs 9,10$).^{336}$ This difference is closely similar to the difference between $\Delta G_{i}{ }^{\circ}\left(\mathrm{BCl}_{3}, \mathrm{CH}_{2} \mathrm{Cl}_{2},-70^{\circ} \mathrm{C}\right)$ of diphenylmethyl chloride $\left(1-\mathrm{H}, \mathrm{H},+12.9 \mathrm{~kJ} \mathrm{~mol}^{-1}\right)^{18}$ and of the tertiary chloride $5-\mathrm{H}, \mathrm{H}\left(+29.4 \mathrm{~kJ} \mathrm{~mol}^{-1}\right.$, see above).

(34) Winstein, S.; Fainberg, S. J. Am. Chem. Soc. 1957, 79, 5937. 


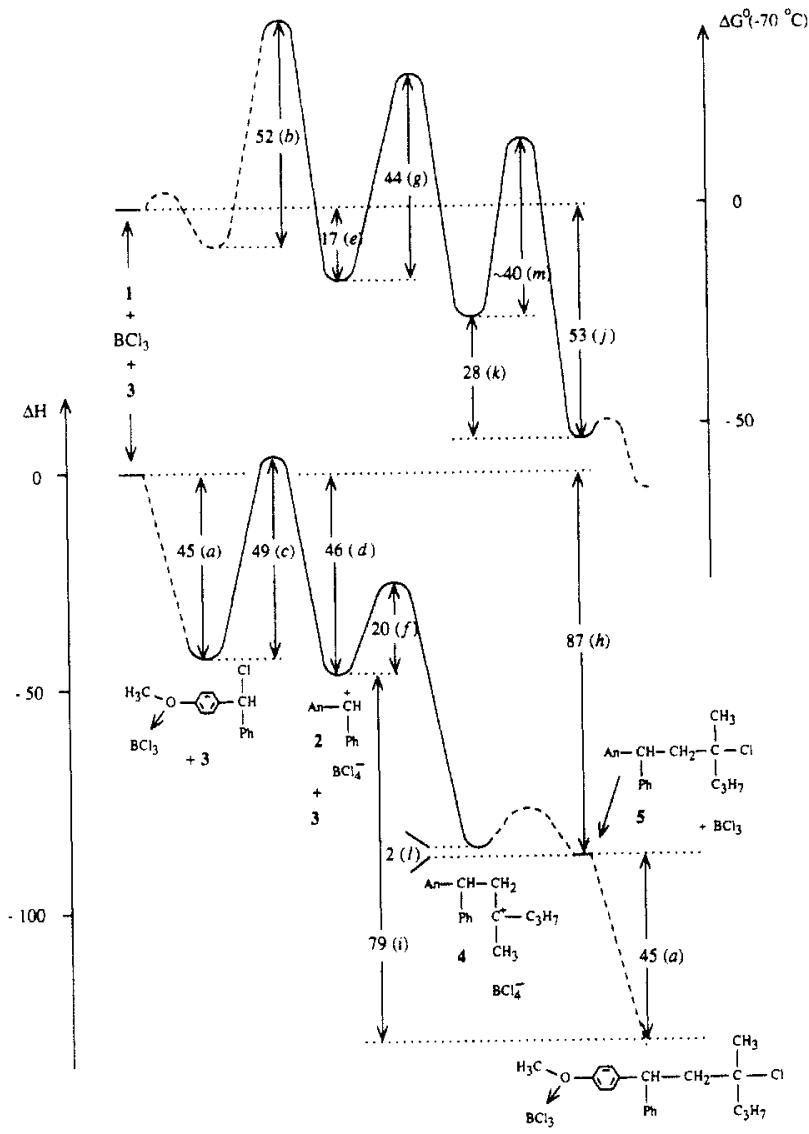

Figure 4. Enthalpy and free energy profiles $\left(\mathrm{kJ} \mathrm{mol}^{-1}\right)$ for the $\mathrm{BCl}_{3}$ promoted reaction of $p$-methoxydiphenylmethyl chloride $\left(\mathbf{1}-\mathrm{OCH}_{3}, \mathrm{H}\right)$ with 2-methyl-1-pentene (3). Unknown sections of the energy profiles are dashed.

3. Construction of the Energy Profiles. The kinetic data reported above and the thermodynamic data reported previously ${ }^{17 a}$ can now be assembled in an energy profile (Figure 4).

In a fast reaction, the rate of which is not known (probably diffusion controlled), $\mathrm{BCl}_{3}$ forms a complex with the ether oxygen. $\Delta H$ for this process ( $a$, Figure 4$)$ is assumed to be identical with that calorimetrically determined for the complexation of the methoxy substituted adducts 5 with $\mathrm{BCl}_{3} .{ }^{17 \mathrm{a}}$ From the ionization rates measured at different temperatures (Table VI), $\Delta H^{*}(c$, Figure 4) and $\Delta G^{*}(b$, Figure 4$)$ have been derived. Calorimetric $^{17 \mathrm{a}}$ and equilibrium studies ${ }^{11,17 \mathrm{a}}$ allow $\mathbf{2 -} \mathbf{O C H}_{3}, \mathrm{H}$ to be located on the $\Delta H\left(d\right.$, Figure 4) and the $\Delta G^{\circ}(e$, Figure 4) scale, respectively. ${ }^{35} \Delta H^{*}(f$, Figure 4$)$ and $\Delta G^{*}(g$, Figure 4$)$ corre-

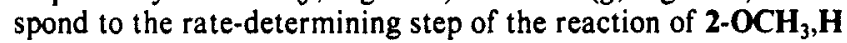
with 3; they are taken from Table III.

Let us skip 4-OCH, 3 and first turn to $5-\mathrm{OCH}_{3}, \mathrm{H}$. The reactions of 1-X,Y with 3 were found to be exothermic by $86.5 \pm$ $2.7 \mathrm{~kJ} \mathrm{~mol}^{-1}$ ( $h$, Figure 4), independent of the nature of $\mathrm{X}$ and $Y{ }^{17 a}$ This value has been corroborated by a Born-Haber cycle: The sum of $h$ and $a$ is almost identical with the heat of ionization of $\mathbf{1 - O C H}, \mathbf{H}(d)$ plus the heat measured on combining 2-

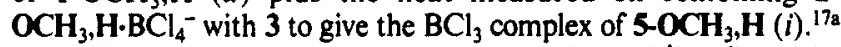
The difference between the two sums $\left(7.3 \mathrm{~kJ} \mathrm{~mol}^{-1}\right)$ reflects the typical error of our calorimetric method. For the addition process $1+3 \rightarrow 5, \Delta S^{\circ}$ can reliably be estimated from group increments ${ }^{36}$ $\left(-164 \mathrm{~J} \mathrm{~mol}^{-1} \mathrm{~K}^{-1}\right)$ which allows us to locate $5-\mathrm{OCH}_{3}, \mathrm{H}$ on the $\Delta G^{\circ}$ scale $(j$, Figure 4$) . \Delta G_{i}^{\circ}\left(\mathrm{BCl}_{3}, \mathrm{CH}_{2} \mathrm{Cl}_{2}\right)$ of $5-0 \mathrm{CH}_{3}, \mathrm{H}(k$, Figure 4) will be in between the values for $\mathbf{5}-\mathbf{C H}_{3}, \mathbf{C H}_{3}$ and 5$\mathrm{OCH}_{3}, \mathrm{OCH}_{3}$ (Section 2), and with the assumption that the ion-

(35) The equilibrium measurements described in ref 17 a avoid the participation of $1-\mathrm{OCH}_{3} \mathrm{H} \rightarrow \mathrm{BCl}_{3}$ complexes.

(36) Benson, S. W. Thermochemical Kinetics, 2nd ed.; Wiley: New York, 1976 (the entropy increment for $\mathrm{C}-(\mathrm{Cl})(\mathrm{C})_{3}$ has to be used with negative sign).

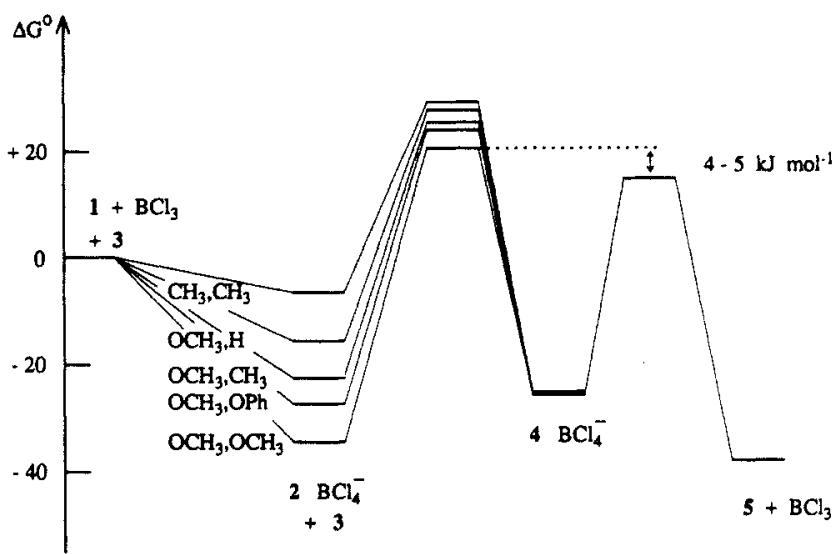

Figure 5. Simplified free energy profiles $\left(\mathrm{kJ} \mathrm{mol}^{-1}\right)$ for the reactions of diarylcarbenium tetrachloroborates $(2-X, Y)$ with 2-methyl-1-pentene (3).

ization entropy of tertiary chlorides and of diarylmethyl chlorides

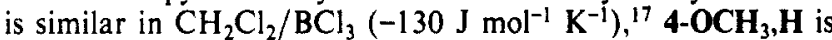
derived to be at approximately the same $\Delta H$ level as the adduct $5-\mathrm{CCH}_{3}, \mathrm{H}\left(l=1.6 \mathrm{~kJ} \mathrm{~mol}^{-1}\right)$.

The $40 \mathrm{~kJ} \mathrm{~mol}^{-1}$ barrier ( $m$, Figure 4) for the chloride transfer from $\mathrm{BCl}_{4}{ }^{-}$to 4 can finally be derived from the change of the rate-determining step in the reaction of $\mathbf{2 -} \mathbf{O C H}_{3}, \mathbf{O C H}_{3} \cdot \mathrm{BCl}_{4}^{-}$with 3 (see Figure 5).

It should be noted that the energy levels of the ions in Figure 4 refer to paired species. For free ions, $\Delta G^{\circ}$ of the ionic species had to be raised by $\sim 14 \mathrm{~kJ} \mathrm{~mol}^{-1}$ (see Section V,1).

In Figure 5, we ignore the details of the ionization step and look at the reactions of the preformed carbenium ions 2 with 3 . If the covalent precursors 1 are selected as reference point for $\Delta G^{\circ}$, the different levels of the carbenium ions $2-X, Y$ are derived from the corresponding equilibrium constants reported previously. ${ }^{11,17 a, 18}$ With the $\Delta G^{*}$ values from Table III we arrive at transition states, which still show the energetic order of the precursor ions, but the spacing has been reduced to approximately one third of the initial value. A late transition state, in accord with the interpretation of the kinetic isotope effects, is indicated by this observation. ${ }^{37}$

From the decrease of the rate of the reaction of 4$\mathbf{O C H}_{3}, \mathbf{O C H}_{3} \cdot \mathrm{BCl}_{4}^{-}$with 3 at low $\left[\mathrm{BCl}_{4}^{-}\right]$(Table II), one can calculate that the ion-pair collapse of $4-\mathrm{OCH}_{3}, \mathrm{OCH}_{3} \cdot \mathrm{BCl}_{4}^{-}$to give 5- $\mathbf{O C H}_{3}, \mathbf{O C H}_{3}$ and $\mathrm{BCl}_{3}$ is approximately $10-20$ times faster than fragmentation, corresponding to $\Delta \Delta G^{*}\left(-70^{\circ} \mathrm{C}\right)$ of $4-5 \mathrm{~kJ} \mathrm{~mol}^{-1}$. From the solvolytic studies reported in Table VII, one can see that the energy differences between the various cations $4-X, Y$ and the transition states leading to $5-X, Y$ are too small to be seen in Figure 5. As the right-hand part of the energy profile is thus independent of $X$ and $Y$, it can be used for the construction of Figure 4 (magnitude of $m$ ).

\section{Conclusion}

The reactions of diarylcarbenium tetrachloroborates 2-X,Y with the 1,1-dialkyl-substituted ethylene 3 in dichloromethane follow simple second-order kinetics and are suited as model reactions for the investigation of carbenium ion additions to alkenes. The limitations are obvious from Figure 5: Benzhydryl chlorides, which yield carbenium ions less stabilized than $\mathbf{2}-\mathrm{CH}_{3}, \mathbf{C H}_{3}$ cannot be fully ionized with $\mathrm{BCl}_{3}$; in these cases, stronger Lewis acids are needed for the ionization. Carbenium ions, which are better stabilized than $\mathbf{2}-\mathbf{O C H}_{3}, \mathbf{O C H}$, react very slowly with 1,1-dialkylethylenes, and the formation of 4 from 2 and 3 becomes reversible.

With the method described in this article it has become possible to directly measure the reactivity of carbenium ions toward $\pi$ nucleophiles. In the succeeding two articles we will report on reactions with other alkenes, but we have also applied this method to the measurement of the reactivities of aromatic and organo-

(37) A detailed discussion of the rate equilibrium relationships will be given in ref 26 . 
metallic compounds. $\pi$-Nucleophiles of widely varying structure can, therefore, be compared with respect to the same electrophiles.

Acknowledgment. We thank Dr. S. Pask and Prof. O. Nuyken for suggesting the kinetic methods used in this work, Prof. M. Marxen and Dipl. Ing. H.-P. Schmidt (Fachhochschule Lübeck) for help during the construction of the work station and Ute Grabis and Monika Rubow for experimental assistance. Financial support by the Deutsche Forschungsgemeinschaft, Stiftung Volkswagenwerk (Kekulê grant to C.S.) and the Fonds der Chemischen Industrie is gratefully acknowledged.

Supplementary Material Available: Tables with concentrations and rate constants at different temperatures for the reactions of 2-X, $\mathbf{Y} \cdot \mathrm{BCl}_{4}{ }^{-}$with 3 (8 pages). Ordering information is given on any current masthead page.

\title{
Kinetics of the Reactions of the p-Methoxy-Substituted Benzhydryl Cation with Various Alkenes and 1,3-Dienes
}

\author{
Herbert Mayr, ${ }^{*}$ Reinhard Schneider, Bernhard Irrgang, and Christian Schade \\ Contribution from the Institut für Chemie der Medizinischen Universität zu Lübeck, Ratzeburger \\ Allee 160, D-2400 Lübeck 1, Federal Republic of Germany. Received October 25, 1989
}

\begin{abstract}
The kinetic method described in the preceding article has been used to determine the rate constants for the reaction of $\left(p-\mathrm{CH}_{3} \mathrm{OC}_{6} \mathrm{H}_{4}\right)\left(\mathrm{C}_{6} \mathrm{H}_{5}\right) \mathrm{CH}^{+} \mathrm{BCl}_{4}^{-}$with 30 alkenes and 1,3-dienes in dichloromethane at -80 to $-30^{\circ} \mathrm{C}$. The second-order rate constants, which reflect the rate of attack of $\left(p-\mathrm{CH}_{3} \mathrm{OC}_{6} \mathrm{H}_{4}\right)\left(\mathrm{C}_{6} \mathrm{H}_{5}\right) \mathrm{CH}^{+}$at these $\pi$-systems strongly depend on the electron-releasing ability of the substituents at the developing carbenium center $\left(\mathrm{H}_{2} \mathrm{C}=\mathrm{C}\left(\mathrm{CH}_{3}\right) \mathrm{R}: \mathrm{R}=\mathrm{H}, 9.39 \times 10^{-4} ; \mathrm{R}\right.$ $=$ vinyl, 15.6; $\mathrm{R}=\mathrm{CH}_{3}, 23.3 ; \mathrm{R}=\mathrm{Ph}, 1450 ; \mathrm{R}=$ cyclopropyl, $5650 \mathrm{~L} \mathrm{~mol}^{-1} \mathrm{~s}^{-1}$ at $\left.-70{ }^{\circ} \mathrm{C}\right)$. The steric effects of substituents at this position are of minor importance $\left(\mathrm{H}_{2} \mathrm{C}=\mathrm{C}\left(\mathrm{CH}_{3}\right) \mathrm{R}: \mathrm{R}=\mathrm{Me}, 23.3 ; \mathrm{R}=\mathrm{Et}, 18.4 ; \mathrm{R}=i-\mathrm{Pr}, 6.08 ; \mathrm{R}=t-\mathrm{Bu}, 1.21 \mathrm{~L}\right.$ $\mathrm{mol}^{-1} \mathrm{~s}^{-1}$ at $-70^{\circ} \mathrm{C}$ ). Methyl groups at the electrophilically attacked vinylic position usually lower $\Delta H^{*}$ and $\Delta S^{*}$, while a uniform effect on the rate constants is not found.
\end{abstract}

In the preceding article we have reported that colorless, covalent products are formed when 2-methyl-1-pentene is added to the colored ionic solutions of several diarylcarbenium tetrachloroborates in $\mathrm{CH}_{2} \mathrm{Cl}_{2},{ }^{1}$ and we have shown that the rate of disappearance of the diarylcarbenium ions, which can be measured photometrically and conductimetrically, equals the rate of attack of the carbenium ions at the alkenes. We report now on the

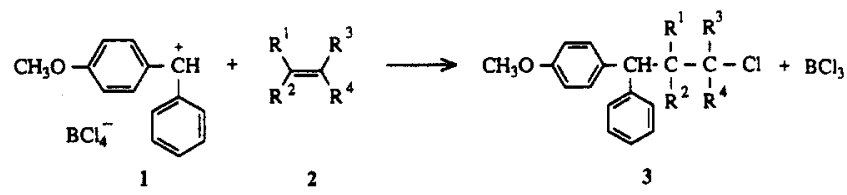

relationship between the structure and reactivity of alkenes and 1,3-dienes employing the p-methoxy-substituted benzhydryl cation 1 as the reference electrophile. This is the first report on absolute rate constants of various vinyl derivatives toward carbenium ions since Dorfman's pioneering work on the reactivity of radiolytically generated benzyl and benzhydryl cations toward some unsaturated hydrocarbons. ${ }^{2}$ A smaller set of data on relative reactivities of alkenes has previously been published by us. ${ }^{3}$

\section{Experimental Section}

The kinetic method has been described in the preceding article, ${ }^{1}$ and the results of the individual kinetic experiments are given in the supplementary material. All reaction products obtained from $1 \cdot \mathrm{BCl}_{4}^{-}$with 2 were characterized by ${ }^{1} \mathrm{H}$ NMR and/or ${ }^{13} \mathrm{C}$ NMR spectroscopy. Spectral and other physical data of the reaction products are documented in ref 4 .

\section{Reaction Products.}

The combination of $1 \cdot \mathrm{BCl}_{4}^{-}$with compounds $2 \mathrm{a}-\mathrm{dd}$ yields $1: 1$ products in almost quantitative yields, as previously described for analogous reactions of other benzhydryl chlorides. ${ }^{3,5}$ For un-

(1) Mayr, H.; Schneider, R.; Schade, C.; Bartl, J.; Bederke, R., preceding paper in this issue.

(2) Wang, J.; Dorfman, L. M. Macromolecules 1980, 13, 63

(3) (a) Mayr, H.; Pock, R. Chem. Ber. 1986, 119, 2473. (b) Pock, R.; Mayr, H. Chem. Ber. 1986, /19, 2497. symmetrical alkenes, the electrophilic attack of 1 takes place regioselectively to give the most stabilized carbenium ion, ${ }^{6}$ and the adducts 3 are usually the exclusive or the predominant products. When secondary alkyl cations are involved as intermediates, 1,2-hydrogen shifts often cannot be avoided, and in the reactions of $1 \cdot \mathrm{BCl}_{4}{ }^{-}$with $\mathbf{2 a - d}$, the main products $3 \mathrm{a}-\mathbf{d}$ are accompanied by some rearranged material. The stereoselectivities of the addition reactions with the $E, Z$-isomeric 2 -butenes $2 \mathbf{b}, \mathbf{c}$ and 1-phenylpropenes $2 s, t$ are comparable to the results reported for the analogous reactions of diphenylmethyl chloride and di$p$-tolylmethyl chloride. ${ }^{7}$ By analogy with an earlier report, ${ }^{8}$ norbornene $2 \mathrm{e}$ reacts with complete Wagner-Meerwein rearrangement to give a 7 -(diarylmethyl)-2-chloronorbornane, and 2-cyclopropylpropene 2dd undergoes the well-known cyclopropylcarbinyl/homoallyl rearrangement with exclusive formation of 1,1-diaryl-6-chloro-3-methyl-3-hexene. ${ }^{3 b}$

The ordinary addition products 3 are accompanied by the indans 4 and 5 , when $1 \cdot \mathrm{BCl}_{4}{ }^{-}$is combined with the alkenes $21-\mathrm{p}, \mathrm{s}, \mathrm{t}$. While 4 and 5 are formed in approximately equal amounts in all cases, the ratio $3 /(4+5)$ strongly depends upon the reaction conditions as described for the reaction of bis(p-methoxyphenyl)carbenium tetrachloroborate with trimethylethylene. ${ }^{1}$ The alkenes $2 \mathrm{~m}$ and $2 p$ react with exclusive or predominant formation of the indans 4 and 5 ( $\left(\mathrm{gem}\right.$-dialkyl effect $^{9}$ ).

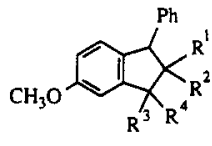

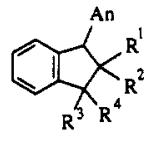

(4) (a) Schneider, R. Dissertation, Universität Erlangen-Nürnberg, 1987. (b) Schade, C. Dissertation, Medizinische Universität zu Lübeck, 1988. (c) Irrgang, B. Dissertation, Medizinische Universität zu Lübeck, 1990

(5) Mayr, H.; Striepe, W. J. Org. Chem. 1983, 48, 1159.

(6) Unsymmetrical $\pi$-systems are attacked at the left $\mathrm{sp}^{2}$ carbon of the formula drawings in Table I.

(7) Pock, R.; Mayr, H.; Rubow, M.; Wilhelm, E. J. Am. Chem. Soc. 1986, $108,7767$.

(8) Pock, R.; Klein, H.; Mayr, H. Chem. Ber, 1986, 119, 929.

(9) Review: Capon, B.; McManus, S. P. Neighboring Group Participation; Plenum Press: New York, 1976, Vol. 1, p 58. 